\title{
Spatial distribution and temporal variations of atmospheric sulfur deposition in Northern China: insights into the potential acidification risks
}

\author{
Y. P. Pan, Y. S. Wang, G. Q. Tang, and D. Wu
}

State Key Laboratory of Atmospheric Boundary Layer Physics and Atmospheric Chemistry (LAPC), Institute of Atmospheric Physics, Chinese Academy of Sciences, Beijing 100029, China

Correspondence to: Y. S. Wang (wys@dq.cern.ac.cn)

Received: 23 August 2012 - Published in Atmos. Chem. Phys. Discuss.: 11 September 2012

Revised: 7 January 2013 - Accepted: 7 January 2013 - Published: 8 February 2013

\begin{abstract}
Atmospheric sulfur (S) deposition via precipitation, particles and gases was investigated at ten sites in Northern China. Measurements were performed continuously between December 2007 and November 2010. The total $\mathrm{S}$ deposition flux in the target area ranged from 35.0 to $100.7 \mathrm{~kg} \mathrm{Sha}^{-1} \mathrm{yr}^{-1}$, noticeably higher than the values documented in Europe, North America, and East Asia. The tensite, 3-yr average total $\mathrm{S}$ deposition was $64.8 \mathrm{~kg} \mathrm{Sha}^{-1} \mathrm{yr}^{-1}$, with $68 \%$ attributed to dry deposition (mainly $\mathrm{SO}_{2}$ ) and the rest to wet deposition. Consequently, the spatial distribution of the total flux was consistent to that of dry deposition, that is, higher values were observed at industrial and urban sites than at agricultural and rural sites. However, the seasonal variation in the total $\mathrm{S}$ deposition was not obvious across the entire year because of opposite seasonal trends in wet and dry deposition. It was found that the wet deposition, without significant spatial and interannual differences, was influenced by the volume of precipitation, the air-column concentrations of $\mathrm{S}$ compounds and in-cloud scavenging. Similar to the wet deposition, the dry-deposited sulfate was also less dependent on the surface concentration. Nevertheless, the regional differences in $\mathrm{SO}_{2}$ dry deposition were mostly explained by the ambient concentration, which is closely associated with local emissions. As expected, the spatial pattern of total S deposition resembled that of the emission inventory, indicating the dramatic anthropogenic imprints on the regional $\mathrm{S}$ budget. Although at most of the study sites the "acid equivalents" deposition of $\mathrm{S}$ was comparable to that of nitrogen $(\mathrm{N})$, the importance of $\mathrm{S}$ in the acidification risks was more pronounced at the industrial sites. The ten-site, 3-yr mean to-
\end{abstract}

tal "acid equivalents" deposition of $\mathrm{S}$ and $\mathrm{N}$ was estimated to be 8.4 (range: $4.2-11.6$ ) $\mathrm{keq} \mathrm{ha}^{-1} \mathrm{yr}^{-1}$, which exceeds the critical loads for natural ecosystems in Northern China. Taking these findings and our previous studies together, a multipollutant perspective and joint mitigation strategies to abate $\mathrm{SO}_{2}$ and $\mathrm{NH}_{3}$ simultaneously in the target area are recommended to protect natural ecosystems from excess acid deposition.

\section{Introduction}

Acid deposition, originating largely from man-made emissions of three gaseous pollutants, namely, sulfur dioxide $\left(\mathrm{SO}_{2}\right)$, nitrogen oxides $\left(\mathrm{NO}_{\mathrm{x}}\right)$ and ammonia $\left(\mathrm{NH}_{3}\right)$, is a global environmental issue because of its transboundary effects on the biogeochemical cycles (Rodhe et al., 2002; Flechard et al., 2011). A particular concern involves acid deposition that exceeds the critical loads of an ecological system, which might cause long-term harmful effects with several deleterious consequences, such as the eutrophication of coastal waters and acidification of lakes, streams and soils, which also reduce species diversity (Reuss et al., 1987; Sickles et al., 2009; Yang et al., 2012b). With acid deposition posing a serious environmental hazard, decision makers need to determine emission control strategies for effective mitigation and the extent of emissions reduction that would promote ecosystem recovery from acid deposition (Driscoll et al., 2001). To address these concerns, it is essential to gain a quantitative knowledge of acid deposition through 
monitoring various acidic species such as $\mathrm{SO}_{2}, \mathrm{NO}_{\mathrm{x}}$ and $\mathrm{NH}_{3}$ as well as particulate and aqueous forms such as sulfate $\left(\mathrm{SO}_{4}^{2-}\right)$, nitrate $\left(\mathrm{NO}_{3}^{-}\right)$and ammonium $\left(\mathrm{NH}_{4}^{+}\right)$.

In recent decades, East Asia has become one of the regions most seriously affected by acid deposition, after Europe and North America, due to increasing emissions of acidic compounds of sulfur (S) and nitrogen (N) (Ayers et al., 2000; Endo et al., 2010; Kuribayashi et al., 2012). China is among the most rapidly developing nations in East Asia and has one of the highest $\mathrm{N}$ deposition levels in the world (Larssen et al., 2006), with a major contribution from reduced $\mathrm{N}\left(\mathrm{NH}_{\mathrm{x}}\right)$ and a minor role of oxidized $\mathrm{N}\left(\mathrm{NO}_{\mathrm{y}}\right)$ (Larssen et al., 2011). Under pressure from various environmental groups, the Chinese government has implemented several different control programs, including the adjustment of its energy structure (Zhao et al., 2009). Consequently, the increasing trend of annual $\mathrm{SO}_{2}$ emissions has leveled off since 2006, after which a declining trend has been observed (Lu et al., 2010). In contrast, reactive $\mathrm{N}$ emissions due to intensive farming and livestock production $\left(\mathrm{NH}_{3}\right)$ as well as traffic and industry $\left(\mathrm{NO}_{\mathrm{x}}\right)$ continue to rise (Liu et al., 2010). These changes in emissions may increase the extent of $\mathrm{N}$ deposition and thereby alter the acid deposition pattern in the future. This argument is partially supported by the fact that the ratio of equivalent concentrations of $\mathrm{SO}_{4}^{2-}$ to $\mathrm{NO}_{3}^{-}$in precipitation have gradually decreased from 5.4 to 1.7 in Beijing (Wang et al., 2012), and from 4.6 to 1.5 in Guangzhou (Fang et al., 2011) over the last three decades. If this trend continues, $\mathrm{HNO}_{3}$ is expected to play a more important role than $\mathrm{H}_{2} \mathrm{SO}_{4}$ in determining the precipitation acidity in the coming decades. However, the aforementioned ratios of larger than unity indicate that the precipitation acidity in China is still primarily caused by $\mathrm{H}_{2} \mathrm{SO}_{4}$ formed via the oxidation of $\mathrm{SO}_{2}$ (Wang et al., 2012). Although the national $\mathrm{SO}_{2}$ emissions will be reduced by around $12 \%$ from 2010 to 2020 if current policies are fully implemented, the areas exceeding the critical loads for soil acidification caused by $\mathrm{S}$ deposition, occurring mainly in eastern and south-central China, will continue to comprise greater than $20 \%$ of the Chinese territory in the 2010s (Zhao et al., 2009). Therefore, monitoring data on $S$ deposition is necessary to evaluate whether the emissions reduction measures currently in place are sufficient for reducing soil acidification (Larssen et al., 2011). Furthermore, enhanced spatial resolution of acid deposition patterns is a key requirement for the application of the critical loads approach to emissions control policies (Aherne and Farrell, 2002). However, longterm data on acid deposition are currently not available on a regional scale in China, although the importance of such data has been previously emphasized (Larssen et al., 2006).

Acid deposition monitoring networks have been established in many regions around the world, including the European Monitoring and Evaluation Programme (EMEP), the US Clean Air Status and Trends Network (CASTNET), the Canadian Air and Precipitation Monitoring Network (CAPMoN), the East Asia Acid Deposition Monitoring Network
(EANET) and the Atmospheric Chemistry Monitoring Network in Africa (IDAF). In China, systematic acid deposition monitoring across the country is absent. Monitoring of acid rain started in the 1980s, but only at a few stations, and suffered from improper device setup and incomplete data series (Zhao et al., 1988). Under the current national monitoring networks, only general urban air quality parameters and rainwater $\mathrm{pH}$ are measured, whereas little effort has been invested in determining the chemistry of the pollutants (Tang et al., 2010). Rapid advances have been made in recent years in the investigation of the chemical constituents responsible for the variations in precipitation $\mathrm{pH}$ (Huang et al., 2008; Sun et al., 2010; Tsai et al., 2011; Wai et al., 2005; Yang et al., 2012a), but most studies have been limited to a single site/year. Acid deposition can occur via the dry deposition of gases and particles and by wet deposition from rain, snow, clouds and fog (Flechard et al., 2011). Unlike precipitation, atmospheric dry deposition of acidifying species has been suggested to be an important process determining the species' lifetime in the atmosphere and their incorporation into various ecosystems. Thus, data describing precipitation chemistry are not sufficient to accurately assess the effects of acid deposition; both the wet and dry deposition flux of S and $\mathrm{N}$ must be determined. Acid deposition is also spatially and temporally variable (Larssen and Carmichael, 2000), highlighting an urgent requirement to organize an up-to-date national deposition network across the country. Although some sites in Southern China have participated in the EANET, the coverage of this network is very sparse in Northern China. To date, limited measurements of $\mathrm{N}$ deposition have been performed for Northern China (Shen et al., 2009), and fieldbased data on $\mathrm{S}$ deposition, particularly dry deposition of the element, are even more scarce.

Northern China is a densely populated and industrialized region with intensive agricultural activities. Associated with the energy expenditure, economic boom and population growth over the past several decades, substantial emissions of acidic precursors have intensified the acid deposition problem in the target area. For example, the precipitation acidity in China remained steady or displayed a decreasing trend during the 1990s. After 2000, however, an increasing trend of precipitation acidity was observed at many sites in Northern China (Tang et al., 2010). Our recent studies identified that the acidity of precipitation in Northern China, generated by $\mathrm{H}_{2} \mathrm{SO}_{4}$ and $\mathrm{HNO}_{3}$, was primarily buffered by $\mathrm{CaCO}_{3}$ and $\mathrm{NH}_{3}$ prior to deposition (Wang et al., 2012). The neutralization of precipitation acidity by alkaline species in the air, however, does not necessarily reduce the potential for the acidification of aquatic and terrestrial ecosystems (Galloway et al., 1984). Evidently, a solution of $\mathrm{CaSO}_{4}$ can cause the short-term acidification of surface waters as a result of cation-exchange reactions in acid soils (Galloway et al., 1987). Neutralization by $\mathrm{NH}_{3}$ is also illusory because the resulting $\mathrm{NH}_{4}^{+}$ions contribute to the acidification of the soil and surface water through chemical processes in the soil 
(Driscoll et al., 2001; Larssen et al., 2006). Therefore, $\mathrm{NH}_{\mathrm{x}}$ must be taken into account when quantifying the potential amount of total acid deposition. Additionally, the exact mode and degree to which $\mathrm{S}$ and $\mathrm{N}$ contribute to the total acid deposition remain largely unknown, although indications of high deposition flux of $\mathrm{N}$ have been reported in a companion paper (Pan et al., 2012).

In the present study, we complement the previous study by the additional estimation of the atmospheric deposition flux of S via precipitation (wet deposition) and as gases and particles (dry deposition), through multi-year monitoring at ten selected sites. The objective of this study was to explore the spatio-temporal variations of atmospheric wet and dry deposition of $\mathrm{S}$ and the causes of the observed patterns in Northern China. Combined with the $\mathrm{N}$ deposition, this data set provides insight into the total deposition of potential acidity on a regional scale. The knowledge gained from this study will provide an up-to-date scientific basis for the validation of emissions inventories and atmospheric chemistry models, and for the crafting of control strategies to reduce emissions and ecological impacts in the target area.

\section{Materials and methods}

\subsection{Site descriptions}

Continuous measurements were carried out during the period from December 2007 to November 2010 at ten sites using the uniform monitoring protocol. Based on their urban geographies, energy structures and ecosystem types, the ten sites were classified into five categories: megacity sites (Beijing-BJ and Tianjin-TJ), industrial sites (Baoding-BD, Tanggu-TG and Tangshan-TS), suburban sites (Yangfang-YF and Cangzhou-CZ), agricultural sites (Luancheng-LC and Yucheng-YC), and a rural mountainous site (Xinglong-XL). Comprehensive descriptions of the stations can be found in Pan et al. (2012).

To interpret the geographical distributions of S deposition, emission patterns of the precursor $\mathrm{SO}_{2}$ must be known. Recently, an Asian emissions inventory for the year 2006 was developed, which includes a database for the study area (Fig. 1a) based on the INTEX-B (Intercontinental Chemical Transport Experiment) mission (Zhang et al., 2009). Hereafter, we refer to this emissions inventory as the "INTEX-B." Anthropogenic $\mathrm{SO}_{2}$ released to the atmosphere in INTEX-B was estimated to be 248,336 and $2281 \mathrm{Gg}$ in Beijing, Tianjin and Hebei province, respectively, making Northern China one of the main "hot spots" of $\mathrm{SO}_{2}$ emissions in Asia. Power plants and industry are the main sources of $\mathrm{SO}_{2}$, contributing more than $70 \%$ of the total emissions. Emissions of $\mathrm{SO}_{2}$ in the target region, aggregated into grids at a resolution of $0.5^{\circ} \times 0.5^{\circ}$, are shown in Fig. $1 \mathrm{~b}$ combined with total S deposition that is categorized into five grades and plotted on the maps. Comparisons between the depositions and emissions are discussed in Sect. 3.4.1.

\subsection{Wet deposition measurements}

Daily rainwater and event-based snow samples were collected using an automatic wet-dry sampler and a clean plastic bucket, respectively. During the 3-yr observation period, a total of 1306 precipitation samples (including rainwater and snow) were collected. All of the precipitation samples were stored, transported, filtered and analyzed following a previously described procedure (Pan et al., 2010a). Of the total number of precipitation samples, $15 \%$ were discarded from the final analysis due to low volumes $(<20 \mathrm{ml})$ that did not permit a complete chemical analysis. The concentrations of $\mathrm{SO}_{4}^{2-}$ in the filtrates of the remaining 1107 samples were determined using an ion chromatography system (Model ICS90, Dionex Corporation, Sunnyvale, CA, USA). The monthly wet deposition flux of $\mathrm{SO}_{4}^{2-}\left(\mathrm{w}_{4}^{2-}, \mathrm{kg} \mathrm{Sha}^{-1}\right.$ month $\left.^{-1}\right)$ was calculated as the product of the volume-weighted mean concentrations of $\mathrm{SO}_{4}^{2-}$ measured in the precipitation and the volume of precipitation measured using a standard rain gauge during the corresponding period. In addition to the discarded samples, some light rain events were not sampled due to malfunctions of the automatic rainfall sampler lid (Pan et al., 2010a). These missed samples, with total depths accounting for less than $6 \%$ of the annual precipitation, did not result in a significant underestimation of ${ }_{\mathrm{w}} \mathrm{SO}_{4}^{2-}$ in the study.

\subsection{Particulate dry deposition measurements}

Dry-deposited particles were collected monthly using a surrogate surface made of polyurethane foam (PUF) filter, which was placed in a glass bucket. The sampling and chemical analysis procedures have been detailed previously (Pan et al., 2010b; Pan et al., 2012) and are only briefly described here. During a rain event, the glass bucket was covered with the lid of the automatic wet-dry collector. After the rainfall ceased, the lid was lifted and rotated to cover the aperture that collected the rainwater. This feature of the automatic sampler is useful for simultaneously collecting rainwater and deposited particles with negligible mixing of the two. After collection, the content of water-extractable $\mathrm{SO}_{4}^{2-}$ in the PUF filter was determined by the ion chromatography system. The monthly dry deposition flux of particulate $\mathrm{SO}_{4}^{2-}$ $\left(\mathrm{pSO}_{4}^{2-}, \mathrm{kg} \mathrm{Sha}^{-1} \mathrm{month}^{-1}\right.$ ) was estimated by dividing the mass of $\mathrm{SO}_{4}^{2-}$ deposited on the PUF filter by the surrogate surface area and the corresponding sampling period. The surrogate surface method used in the study is ineffective for the capture of fine particles. Therefore, the $\mathrm{SO}_{4}^{2-}$ measured here has the potential for underestimation and represents a rather conservative estimation.

Note that dry deposition is a continuous process that happens at all times. The process is faster when the surface is wet or during wet periods (due to stronger turbulence and/or a 

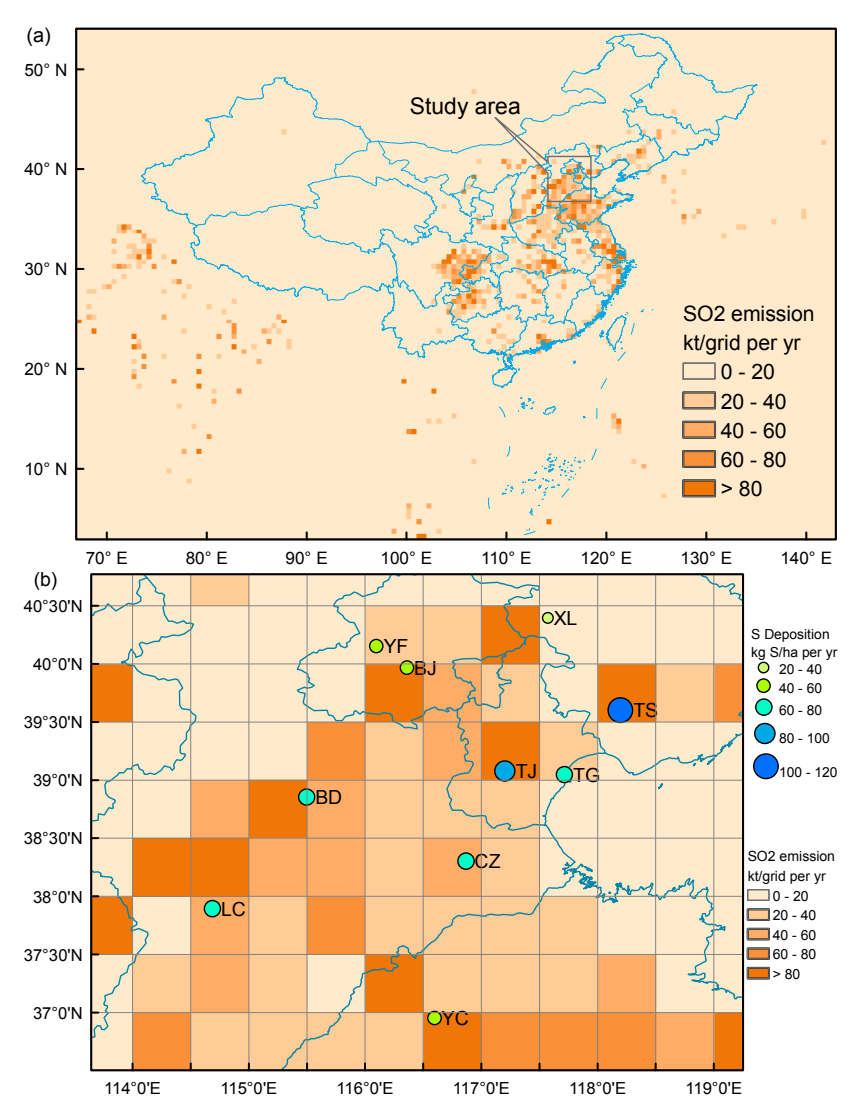

Fig. 1. Locations of the study area (a) and the sampling sites (b) in Northern China with $\mathrm{SO}_{2}$ emission distributions. The total sulfur deposition data are means of 3-yr observations from December 2007 to November 2010. The emission data of $\mathrm{SO}_{2}$ are from 2006 (Zhang et al., 2009), with a resolution of $0.5^{\circ} \times 0.5^{\circ}$. The definition of the site codes is found in Sect. 2.1.

stickier surface compared to dry periods). This phenomenon is not reproduced in the design of any artificial collection device (Wesely and Hicks, 2000). Therefore, the use of a deposition plate resulted in the omission of dry deposition during wet periods and in the underestimation of the total dry deposition. However, this uncertainty is relatively unimportant in this study because the dry periods are long in Northern China.

\subsection{Gaseous dry deposition estimation}

The inferential method, which combines the measured concentration and a modeled dry deposition velocity $\left(V_{\mathrm{d}}\right)$, was used to estimate the gaseous dry deposition flux (Schwede et al., 2011). The gaseous measurements of $\mathrm{SO}_{2}$ correspond to monthly integrated samples collected using passive diffusing techniques (Analysts, CNR-Institute of Atmospheric Pollution, Rome, Italy). The ambient $\mathrm{SO}_{2}$ concentrations were calculated based on the $\mathrm{SO}_{4}^{2-}$ levels in the extracts of the diffusive samplers corrected by the local temperature and humidity conditions (Costabile et al., 2006). The hourly
$V_{\mathrm{d}}$ of $\mathrm{SO}_{2}$ was simulated using the Models-3/Community Multiscale Air Quality (CMAQ v4.6) system (Byun and Ching, 1999). Detailed descriptions of the computation of $V_{\mathrm{d}}$ can be found in a previously published work (Pan et al., 2012). The measured concentrations of $\mathrm{SO}_{2}$ were multiplied by the average $V_{\mathrm{d}}$ during the corresponding period to estimate the monthly gaseous dry deposition flux of $\mathrm{SO}_{2}\left(\mathrm{gSO}_{2}\right.$, $\mathrm{kg} \mathrm{Sha}^{-1}$ month$^{-1}$ ). It is important to note that the inferential method is not ideal for determining $\mathrm{gSO}_{2}$ but is an alternative operational tool used in the absence of data measured at the regional scale (Flechard et al., 2011). Although there are uncertainties in the $V_{\mathrm{d}}$ simulations (Pan et al., 2012), the $\mathrm{SO}_{2}$ flux was evaluated using the inferential method to approximate its contribution to the $\mathrm{S}$ budget and thus to the acid deposition, keeping in mind that this measure must be validated with micrometeorological measurements in future field studies.

\subsection{Statistics}

To evaluate the total atmospheric $\mathrm{S}$ deposition flux $\left(\mathrm{C}_{\mathrm{t}} \mathrm{SO}_{\mathrm{x}}\right)$, we compiled the flux data in terms of $\mathrm{S}$ from dry-deposited particles, gas and precipitation chemistry measurements. The annual ${ }_{\mathrm{w}} \mathrm{SO}_{4}^{2-},{ }_{\mathrm{p}} \mathrm{SO}_{4}^{2-},{ }_{\mathrm{g}} \mathrm{SO}_{2}$ and ${ }_{\mathrm{t}} \mathrm{SO}_{\mathrm{x}}$ (generally expressed in units of $\mathrm{kg} \mathrm{Sha}^{-1} \mathrm{yr}^{-1}$ ) were integrated from monthly flux data sets.

The total potential acidifying deposition flux ( $\mathrm{N}$ plus $\mathrm{S}$, hereafter referred to as total acid deposition) is given in mole of protons $\left(\mathrm{H}^{+}\right) \mathrm{ha}^{-1} \mathrm{yr}^{-1}$ (here converted to keq $\left.\mathrm{ha}^{-1} \mathrm{yr}^{-1}\right)$ by considering that one mole of total inorganic $\mathrm{N}\left(\mathrm{NH}_{\mathrm{x}}+\mathrm{NO}_{\mathrm{y}}\right)$ forms one mole $\mathrm{H}^{+}$in the soil and that one mole of ${ }_{\mathrm{t}} \mathrm{SO}_{\mathrm{x}}\left({ }_{\mathrm{w}} \mathrm{SO}_{4}^{2-}+{ }_{\mathrm{p}} \mathrm{SO}_{4}^{2-}+{ }_{\mathrm{g}} \mathrm{SO}_{2}\right)$ results in two $\mathrm{H}^{+}$. This calculation accounts for the soil microbial transformation of $\mathrm{NH}_{4}^{+}$to $\mathrm{NO}_{3}^{-}$with the release of $\mathrm{H}^{+}$. The $\mathrm{N}$ deposition data are presented in (Pan et al. (2012).

A one-way analysis of variance (ANOVA) and nonparametric tests were performed to examine the significance of differences in the annual flux of S for all ten sites over the three years of the study. A linear regression analysis was used to investigate the relationships between the deposition flux and the concentration data or the volume of precipitation. All statistical analyses were conducted using the software SPSS 11.5 (SPSS Inc., Chicago, IL, USA) and Origin 8.0 (Origin Lab Corporation, Northampton, MA, USA).

\section{Results and discussion}

\subsection{Dry deposition of $\mathrm{SO}_{2}$}

\subsubsection{Ambient concentrations and $V_{\mathrm{d}}$ of $\mathrm{SO}_{2}$}

To provide a detailed interpretation of the variation of ${ }_{\mathrm{g}} \mathrm{SO}_{2}$, ambient concentrations and $V_{\mathrm{d}}$ of $\mathrm{SO}_{2}$ at the ten sites during the 3-yr study period are presented in Fig. 2. The annual mean concentrations of $\mathrm{SO}_{2}$ are in the range 
of $8.5-60.5 \mu \mathrm{g} \mathrm{m}^{-3}$, in close agreement with values of $0.9-95 \mu \mathrm{g} \mathrm{S} \mathrm{m}{ }^{-3}$ that were recently measured across China (Meng et al., 2010; Lin et al., 2012). However, the 10-site average concentrations of $\mathrm{SO}_{2}$ observed in the present study $\left(27.5 \mu \mathrm{g} \mathrm{m}^{-3}\right.$ ) were 3 times that of the reported values at one regional background Global Atmosphere Watch station $\left(<10 \mu \mathrm{g} \mathrm{S} \mathrm{m}^{-3}\right)$ in Northern China (Meng et al., 2010). Even at the rural site, $\mathrm{XL}$, the 3 -yr mean concentrations of $\mathrm{SO}_{2}$ $\left(12.4 \mu \mathrm{g} \mathrm{S} \mathrm{m}^{-3}\right.$ ) were significantly higher than the values observed at rural/background sites in China (Meng et al., 2010) and Japan (Endo et al., 2010), indicating that $\mathrm{SO}_{2}$ pollution in the target area is severe.

It is also worth noting that the annual mean concentrations of $\mathrm{SO}_{2}$ decreased considerably from 2008 to 2009 and 2010 at each site except at TG (Fig. 2a). A similar distinct decrease of the column concentration of $\mathrm{SO}_{2}$ was observed by satellite measurements over East China after 2007 (Zhang et al., 2012). Such a declining trend of tropospheric $\mathrm{SO}_{2}$ in recent years may be caused by the policy of the Chinese government directed toward the reduction of $\mathrm{SO}_{2}$ emissions in $2006(\mathrm{Lu}$ et al., 2010; Lin et al., 2012).

The mean monthly $V_{\mathrm{d}}$ of $\mathrm{SO}_{2}$ simulated for the three years ranged from $1.5-7.7 \mathrm{~mm} \mathrm{~s}^{-1}$ (Fig. 2d). These results are comparable to those of a number of previous studies (Brook et al., 1999; Endo et al., 2010; Feliciano et al., 2001; Tsai et al., 2010). The $V_{\mathrm{d}}$ used here is within the reasonable range and provides a detailed data set with enhanced seasonal and spatial resolution for Northern China with respect to the study of dry deposition.

\subsubsection{Spatial variations of $\mathrm{gSO}_{2}$}

The mean annual $\mathrm{gSO}_{2}$ at the ten sites during the 3-yr period ranged from 16.0 to $55.2 \mathrm{~kg} \mathrm{Sha}^{-1} \mathrm{yr}^{-1}$ (Table 1). The overall mean $\mathrm{gSO}_{2}$ in this study reached $32.4 \mathrm{~kg} \mathrm{Sha}^{-1} \mathrm{yr}^{-1}$, which is much higher than the values modeled in South Korea (3.5 $\left.\mathrm{kg} \mathrm{Sha}^{-1} \mathrm{yr}^{-1}\right)$ (Park and Lee, 2003), Japan (approximately $3.1 \mathrm{~kg} \mathrm{Sha}^{-1} \mathrm{yr}^{-1}$ ) (Endo et al., 2010) and the values determined over a coniferous canopy in The Netherlands $\left(4.3 \mathrm{~kg} \mathrm{Sha}^{-1} \mathrm{yr}^{-1}\right)$ using the aerodynamic gradient technique (Wyers and Duyzer, 1997).

Given the influence of high concentrations of $\mathrm{SO}_{2}$ (Fig. 2a), it is not surprising that the ${ }_{\mathrm{SO}_{2}}$ at the industrial sites TJ and TS reached 48.8 and $55.2 \mathrm{~kg} \mathrm{Sha}^{-1} \mathrm{yr}^{-1}$, respectively (Table 1). However, these values are much lower than the results from the farmland in Jiangxi, China (79.6 $\mathrm{kg} \mathrm{Sha}^{-1} \mathrm{yr}^{-1}$ ), which is attributable to the influence of $\mathrm{SO}_{2}$ emissions from anthropogenic sources (Wang et al., 2003). In general, the monthly mean $\mathrm{gSO}_{2}$ was significantly higher at TJ and TS than at other sites, with the exception of $\mathrm{BD}$ and $\mathrm{LC}(p>0.05)$.

As shown in Table 1, the results demonstrated a relatively high $\mathrm{gSO}_{2}$ at $\mathrm{LC}, \mathrm{BD}, \mathrm{TG}, \mathrm{CZ}$ and $\mathrm{YC}$, with values of 38.9 , $37.8,33.6,28.9$ and $27.3 \mathrm{~kg} \mathrm{Sha}^{-1} \mathrm{yr}^{-1}$, respectively, and no significantly different monthly mean values were found
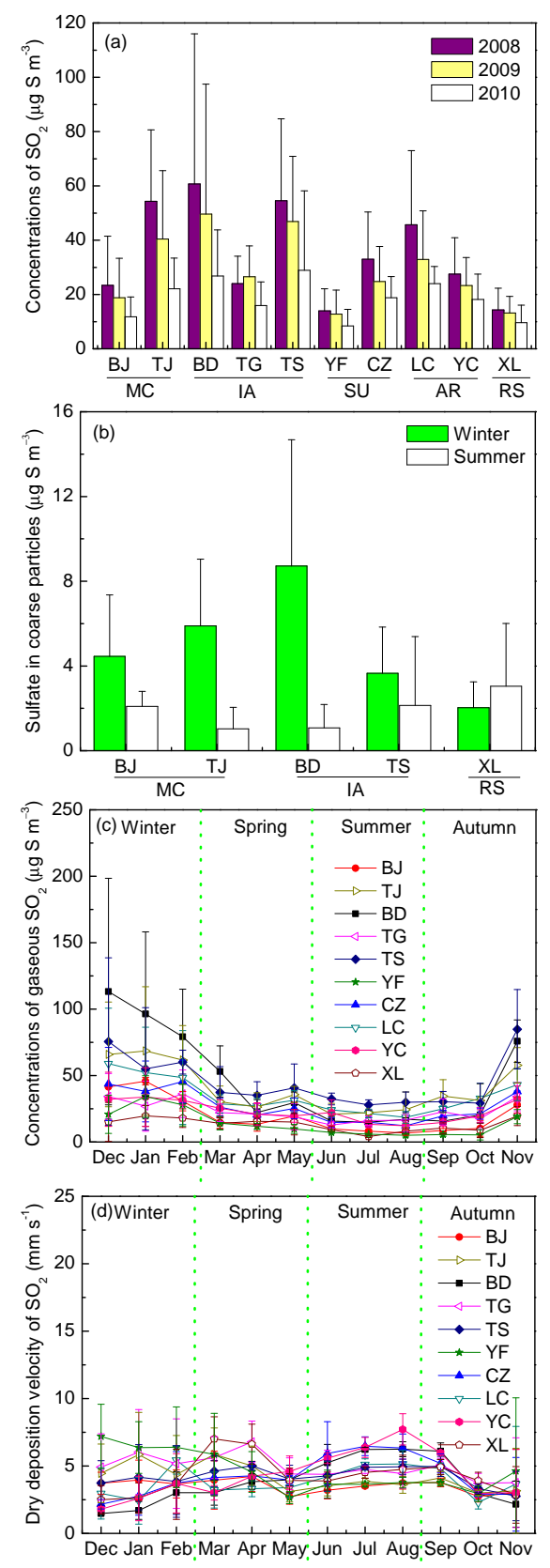

Fig. 2. Spatial variations of the concentrations and dry deposition velocities of $\mathrm{SO}_{2}$ and sulfate in Northern China. The concentration data of $\mathrm{SO}_{2}$ are monthly means during the $3-\mathrm{yr}$ observations, with the error bars denoting standard deviation (a). The concentrations of sulfate in coarse particles during the winter (from December 2009 to February 2010) and summer (from June to August 2010) at the five sites are derived from (Sun, 2011), with the error bars denoting standard deviation (b). More sampling and analysis information was available in our previous paper (Pan et al., 2012). MC, IA, SU, $\mathrm{AR}$ and RS denote urban, industrial, suburban, agricultural and rural sites, respectively. Seasonal variations of the concentrations (c) and dry deposition velocities (d) of $\mathrm{SO}_{2}$ shown are the monthly mean \pm standard deviations of 3-yr observations (from December 2007 to November 2010). The definition of the site codes is found in Sect. 2.1. 
Table 1. Wet and dry deposition flux of sulfur $\left(\mathrm{kg} \mathrm{S} \mathrm{ha}^{-1} \mathrm{yr}^{-1}\right)$ in Northern China.

\begin{tabular}{|c|c|c|c|c|c|c|}
\hline \multirow[t]{2}{*}{ Location } & \multirow[t]{2}{*}{ Site } & \multirow[t]{2}{*}{ Coordinates } & \multirow[t]{2}{*}{ Wet } & \multicolumn{2}{|c|}{ Dry } & \multirow{2}{*}{$\begin{array}{l}\text { Total deposition } \\
\text { (Wet + Dry) }\end{array}$} \\
\hline & & & & Particle & Gas & \\
\hline \multirow[t]{2}{*}{ Urban } & $\mathrm{BJ}$ & $\begin{array}{l}39.96^{\circ} \mathrm{N} \\
116.36^{\circ} \mathrm{E}\end{array}$ & $21.5 \pm 3.7^{\mathrm{a}}$ & $9.3 \pm 3.3^{\mathrm{a}, \mathrm{b}, \mathrm{c}}$ & $19.5 \pm 5.4^{\mathrm{a}, \mathrm{b}, \mathrm{c}}$ & $50.3 \pm 6.5^{\mathrm{a}, \mathrm{b}}$ \\
\hline & $\mathrm{TJ}$ & $\begin{array}{l}39.08^{\circ} \mathrm{N} \\
117.21^{\circ} \mathrm{E}\end{array}$ & $15.5 \pm 5.8^{\mathrm{a}}$ & $19.5 \pm 2.5^{\mathrm{c}, \mathrm{d}}$ & $48.8 \pm 21.9^{\mathrm{d}, \mathrm{e}}$ & $83.8 \pm 25.2^{\mathrm{c}, \mathrm{d}}$ \\
\hline \multirow[t]{3}{*}{ Industrial } & $\mathrm{BD}$ & $\begin{array}{l}38.85^{\circ} \mathrm{N}, \\
115.50^{\circ} \mathrm{E}\end{array}$ & $18.8 \pm 5.5^{\mathrm{a}}$ & $15.2 \pm 3.6^{\mathrm{b}, \mathrm{c}, \mathrm{d}}$ & $37.8 \pm 9.1^{\mathrm{b}, \mathrm{c}, \mathrm{d}, \mathrm{e}}$ & $71.7 \pm 12.7^{\mathrm{b}, \mathrm{c}}$ \\
\hline & TG & $\begin{array}{l}39.04^{\circ} \mathrm{N}, \\
117.72^{\circ} \mathrm{E}\end{array}$ & $24.7 \pm 2.9^{\mathrm{a}}$ & $13.1 \pm 6.4^{\mathrm{a}, \mathrm{b}, \mathrm{c}}$ & $33.6 \pm 13.6^{\mathrm{a}, \mathrm{b}, \mathrm{c}, \mathrm{d}}$ & $71.4 \pm 10.8^{\mathrm{b}, \mathrm{c}}$ \\
\hline & TS & $\begin{array}{l}39.60^{\circ} \mathrm{N} \\
118.20^{\circ} \mathrm{E}\end{array}$ & $20.8 \pm 3.6^{\mathrm{a}}$ & $24.8 \pm 12.1^{\mathrm{d}}$ & $55.2 \pm 20.3^{\mathrm{e}}$ & $100.7 \pm 9.0^{\mathrm{d}}$ \\
\hline \multirow[t]{2}{*}{ Suburban } & YF & $\begin{array}{l}40.15^{\circ} \mathrm{N}, \\
116.10^{\circ} \mathrm{E}\end{array}$ & $19.2 \pm 8.3^{\mathrm{a}}$ & $8.4 \pm 1.9^{a, b}$ & $18.2 \pm 5.1^{\mathrm{a}, \mathrm{b}}$ & $45.9 \pm 4.1^{\mathrm{a}, \mathrm{b}}$ \\
\hline & $\mathrm{CZ}$ & $\begin{array}{l}38.30^{\circ} \mathrm{N} \\
116.87^{\circ} \mathrm{E}\end{array}$ & $22.9 \pm 8.1^{\mathrm{a}}$ & $9.6 \pm 5.6^{\mathrm{a}, \mathrm{b}, \mathrm{c}}$ & $28.9 \pm 5.6^{\mathrm{a}, \mathrm{b}, \mathrm{c}}$ & $61.4 \pm 7.6^{\mathrm{a}, \mathrm{b}, \mathrm{c}}$ \\
\hline \multirow[t]{2}{*}{ Agricultural } & $\mathrm{LC}$ & $\begin{array}{l}37.89^{\circ} \mathrm{N}, \\
114.69^{\circ} \mathrm{E}\end{array}$ & $17.9 \pm 6.5^{\mathrm{a}}$ & $13.4 \pm 3.2^{\mathrm{a}, \mathrm{b}, \mathrm{c}}$ & $38.9 \pm 11.8^{\mathrm{c}, \mathrm{d}, \mathrm{e}}$ & $70.1 \pm 17.6^{\mathrm{b}, \mathrm{c}, \mathrm{d}}$ \\
\hline & $\mathrm{YC}$ & $\begin{array}{l}36.85^{\circ} \mathrm{N} \\
116.55^{\circ} \mathrm{E}\end{array}$ & $20.3 \pm 3.2^{\mathrm{a}}$ & $10.3 \pm 3.5^{\mathrm{a}, \mathrm{b}, \mathrm{c}}$ & $27.3 \pm 6.0^{\mathrm{a}, \mathrm{b}, \mathrm{c}}$ & $58.0 \pm 2.8^{\mathrm{a}, \mathrm{b}, \mathrm{c}}$ \\
\hline Rural & $\mathrm{XL}$ & $\begin{array}{l}40.38^{\circ} \mathrm{N} \\
117.57^{\circ} \mathrm{E}\end{array}$ & $14.6 \pm 4.3^{\mathrm{a}}$ & $4.4 \pm 1.7^{\mathrm{a}}$ & $16.0 \pm 2.6^{\mathrm{a}}$ & $35.0 \pm 5.1^{\mathrm{a}}$ \\
\hline \multicolumn{3}{|c|}{ 10-site average } & $19.6 \pm 3.1$ & $12.8 \pm 5.9$ & $32.4 \pm 13.1$ & $64.8 \pm 19.1$ \\
\hline
\end{tabular}

The sulfur deposition data are annual means \pm standard deviation of 3-yr observations (from December 2007 to November 2010). Values within a column sharing the same superscript letter are not significantly different (one-way ANOVA with Tukey's HSD; $p<0.05$ ). Definition of site codes is found in Sect. 2.1.

among the former four sites $(p>0.05)$. Although the concentrations of $\mathrm{SO}_{2}$ at $\mathrm{LC}$ and $\mathrm{BD}$ were considerably higher than at $\mathrm{TG}$ and $\mathrm{CZ}$, the reverse was true for $V_{\mathrm{d}}$, resulting in the comparable results of $\mathrm{gSO}_{2}$ at these four sites. In addition, the monthly mean $\mathrm{gSO}_{2}$ at $\mathrm{BJ}, \mathrm{YF}$ and $\mathrm{XL}$ was notably lower than at the other sites $(p<0.05)$, with mean annual values of $19.5,18.2$ and $16.0 \mathrm{~kg} \mathrm{~S} \mathrm{ha}^{-1} \mathrm{yr}^{-1}$, respectively, which corresponds to low concentrations of $\mathrm{SO}_{2}$. In general, the spatial variations of $\mathrm{gSO}_{2}$ illustrated higher flux at certain industrial and urban sites than at agricultural and rural sites. This finding is not surprising because gas dry deposition is mostly controlled by surface concentration, which is closely associated with local emissions (Balestrini et al., 2000).

\subsubsection{Interannual variations of $\mathrm{gSO}_{2}$}

The year-to-year variations in the annual average ${ }_{\mathrm{g}} \mathrm{SO}_{2}$ were comparatively small at each site with the exception of $\mathrm{BD}$, CZ, TG, TJ and TS, which showed significantly lower values in 2010 than in 2009 or $2008(p<0.05)$. This finding is inconsistent with the decreasing trend of $\mathrm{SO}_{2}$ emissions after the year 2006 due to the source-control measures implemented in China (Lu et al., 2010). As the gas dry-deposition flux is determined by both the concentrations and $V_{\mathrm{d}}$ of the target species, the flux estimates can be significantly different because of the differences in the simulated $V_{\mathrm{d}}$ (Pan et al., 2012). We believe that the concentration of $\mathrm{SO}_{2}$ may serve as a better index than the flux data for tracking the interannual trends of emissions. As discussed above, it was observed that the $\mathrm{SO}_{2}$ concentrations declined year to year in the target area (Fig. 2a). In general, the 10-site average concentrations of $\mathrm{SO}_{2}$ in 2009 reduced by approximately $18 \%$ compared to 2008 and further declined by $36 \%$ from 2009 to 2010, which corresponds closely to the decreasing tendencies of $\mathrm{SO}_{2}$ column concentrations in recent years (Zhang et al., 2012). Although the differences among the three years are not significant at certain sites $(p>0.05)$, it is important to note that ${ }_{\mathrm{g}} \mathrm{SO}_{2}$ also tended to decline between 2008/2009 and 2010 . Overall, the 10-site average $\mathrm{gSO}_{2}$ in 2010 was $38 \%$ and $45 \%$ lower than in 2008 and 2009, respectively. To check whether 
the control measures are working as anticipated, in future work, the long-term trends of S deposition should be investigated in the context of evaluating its impacts on ecosystems.

\subsubsection{Seasonal variations of $\mathrm{gSO}_{2}$}

The monthly mean ${ }_{\mathrm{g}} \mathrm{SO}_{2}$ during the 3-yr period ranged from 0.4 to $9.0 \mathrm{~kg} \mathrm{~S} \mathrm{ha}^{-1}$ month $^{-1}$ (Fig. 3a). Between March and September, the seasonal variation of $\mathrm{gSO}_{2}$ was not distinct at most of the sites, most likely because they primarily originate from industrial emissions that have less of a seasonal cycle. In contrast, higher ${ }_{\mathrm{g}} \mathrm{SO}_{2}$ was found during winter and late autumn (November) at sites TS, TJ, LC, TG and BD. The notably high $\mathrm{gSO}_{2}$ in cold months suggests the importance of the source, which is related to the fact that extra coal is consumed for home heating. Seasonal variations of $\mathrm{gSO}_{2}$ are consistent to the ambient concentrations of $\mathrm{SO}_{2}$ (Fig. 2c). In addition, the statistical results demonstrated a moderately linear relationship between monthly flux and monthly concentrations of $\mathrm{SO}_{2}\left(0.41<r^{2}<0.77, p<0.05\right)$ at most of sites except for CZ $\left(r^{2}=0.13\right)$ and YC $\left(r^{2}=0.19\right)$. These results indicated that the seasonal variations of $\mathrm{gSO}_{2}$ can mostly be explained by seasonal variations of $\mathrm{SO}_{2}$ surface concentrations.

\subsection{Dry deposition of particulate $\mathrm{SO}_{4}^{2-}$}

\subsubsection{Temporal variations of $\mathrm{pSO}_{4}^{2-}$ vs. $\mathrm{SO}_{4}^{2-}$ concentrations in coarse particles}

During the 3-yr observation campaign, the mean monthly $\mathrm{pSO}_{4}^{2-}$ ranged from 0.1 to $5.1 \mathrm{~kg} \mathrm{Sha}^{-1}$ month $^{-1}$ (Fig. 3b). At most of the sites, the ${ }_{\mathrm{p}} \mathrm{SO}_{4}^{2-}$ was higher in the winter and the early spring than in the other seasons. A similar trend has been observed at an urban location in India (Saxena et al., 1997). Because the majority of the dry-deposited $\mathrm{SO}_{4}^{2-}$ is associated with coarse particles (Lestari et al., 2003), the seasonal variations of $\mathrm{SO}_{4}^{2-}$ are expected to be correlated with the ambient concentrations of $\mathrm{SO}_{4}^{2-}$ in coarse particulate matter. This expectation is verified by our size-resolved compositional analyses determined for sites $\mathrm{BJ}, \mathrm{TJ}, \mathrm{BD}$, TS and XL in 2009-2010 (Sun, 2011), which reveal that the concentrations of $\mathrm{SO}_{4}^{2-}$ in the coarse particulate matter (larger than $2.1 \mu \mathrm{m}$ ) were higher in winter than in summer (Fig. 2b, except for $\mathrm{XL}$ ). The maximum concentrations of $\mathrm{SO}_{4}^{2-}$ in winter coincide with the period of home heating in the target area. This pattern is more pronounced in the industrial and urban areas with high population density and, therefore, huge coal consumption, even at a relatively small spatial scale (e.g., TJ, TS and BD). In contrast, during summer, when the atmospheric $\mathrm{SO}_{\mathrm{x}}$ emissions are much lower, efficient wet deposition further decreases $\mathrm{SO}_{4}^{2-}$ in the air, and therefore, ${ }_{\mathrm{p}} \mathrm{SO}_{4}^{2-}$ is lower. In general, the mean monthly $\mathrm{SO}_{4}^{2-}$ was not significantly different $(p>0.05)$ between different years at most of the sites except for BD, BJ, CZ, TG and TS. In these five sites, the $\mathrm{SO}_{4}^{2-}$ was found to be lower in 2009 than in 2008 and 2010, indicating interannual variations of ${ }_{\mathrm{p}} \mathrm{SO}_{4}^{2-}$.

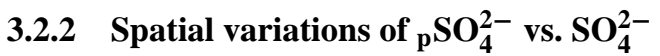 concentrations in coarse particles}

The mean annual $\mathrm{SO}_{4}^{2-}$ in Northern China was within the range of $4.4-24.8 \mathrm{~kg} \mathrm{Sha}^{-1} \mathrm{yr}^{-1}$ with a mean of $12.8 \mathrm{~kg} \mathrm{Sha}^{-1} \mathrm{yr}^{-1}$ during the 3 -yr period (Table 1 ). This value is comparable to that from Jiangxi, China (6.7 $\mathrm{kg} \mathrm{S} \mathrm{ha}^{-1} \mathrm{yr}^{-1}$ ) (Wang et al., 2003), and Chicago, IL, US (3.7-14.6 $\mathrm{kg} \mathrm{S} \mathrm{ha}^{-1} \mathrm{yr}^{-1}$ ), estimated using a dry-deposition velocity model (Lestari et al., 2003). However, this value is much higher than the $\mathrm{pSO}_{4}^{2-}$ modeled for South Korea $\left(0.6 \mathrm{~kg} \mathrm{Sha}^{-1} \mathrm{yr}^{-1}\right)$ (Park and Lee, 2003), a coniferous canopy in The Netherlands $\left(1.8 \mathrm{~kg} \mathrm{Sha}^{-1} \mathrm{yr}^{-1}\right)$ determined using the aerodynamic gradient technique (Wyers and Duyzer, 1997), and values for Japan (approximately $3.2 \mathrm{~kg} \mathrm{Sha}^{-1} \mathrm{yr}^{-1}$ ) estimated using the inferential method (Endo et al., 2010).

The highest mean annual $\mathrm{pSO}_{4}^{2-}$ during the 3 -yr period was found at site TS, with a value of $24.8 \mathrm{~kg} \mathrm{Sha}^{-1} \mathrm{yr}^{-1}$ (Table 1), which is significantly higher than the other sites with the exception of TJ and BD $(p>0.05)$. The second highest result was observed at site $\mathrm{TJ}\left(19.5 \mathrm{~kg} \mathrm{Sha}^{-1} \mathrm{yr}^{-1}\right)$, followed by $\mathrm{BD}, \mathrm{LC}$ and TG, with values of 15.2, 13.4 and $13.1 \mathrm{~kg} \mathrm{Sha}^{-1} \mathrm{yr}^{-1}$, respectively. However, the monthly mean ${ }_{\mathrm{p}} \mathrm{SO}_{4}^{2-}$ at these sites was not significantly different $(p>0.05)$. The enhanced ${ }_{\mathrm{p}} \mathrm{SO}_{4}^{2-}$ at the industrial sites TS, $\mathrm{TJ}$ and BD most likely resulted from the high levels of ambient $\mathrm{SO}_{4}^{2-}$ in the atmosphere of the respective cities, which is more pronounced in winter (Fig. 2b). The ${ }_{\mathrm{p}} \mathrm{SO}_{4}^{2-}$ was comparable for sites $\mathrm{YC}, \mathrm{CZ}, \mathrm{BJ}$ and $\mathrm{YF}$, namely, 10.3, 9.6, 9.3 and $8.4 \mathrm{~kg} \mathrm{Sha}^{-1} \mathrm{yr}^{-1}$, respectively. The annual mean ${ }_{\mathrm{p}} \mathrm{SO}_{4}^{2-}$ was lowest at site $\mathrm{XL}\left(4.4 \mathrm{~kg} \mathrm{Sha}^{-1} \mathrm{yr}^{-1}\right)$ as a result of low concentrations of ambient $\mathrm{SO}_{4}^{2-}$, especially in winter (Fig. 2b). The monthly mean flux at this site differed significantly from those at the other sites $(p<0.05)$, which most likely reflects the lower emissions in the rural areas.

Similar to the spatial pattern of the $\mathrm{gSO}_{2}$, the annual mean ${ }_{\mathrm{p}} \mathrm{SO}_{4}^{2-}$ was higher at the industrial and urban sites (e.g., TS and TJ) than at the suburban and rural sites (e.g., XL). This spatial variation was in close agreement with the concentrations of $\mathrm{SO}_{4}^{2-}$ observed at these sites in winter but not in summer (Fig. 2b), indicating that the annual $\mathrm{SO}_{4}^{2-}$ partially depends on the ambient concentration. Although LC is located in an agricultural area, the influence of an $\mathrm{SO}_{\mathrm{x}}$ plume emitted from the industry sources of Shijiazhuang city (the capital of Hebei province) might be the reason behind the relatively high annual $\mathrm{SO}_{4}^{2-}$ that was observed at site $\mathrm{LC}$. Compared to TJ and TG, another megacity of $\mathrm{BJ}$ and its suburban site YF had relatively low $\mathrm{SOO}_{4}^{2-}$, although the concentrations of $\mathrm{SO}_{4}^{2-}$ in summer were higher at the $\mathrm{BJ}$ site 

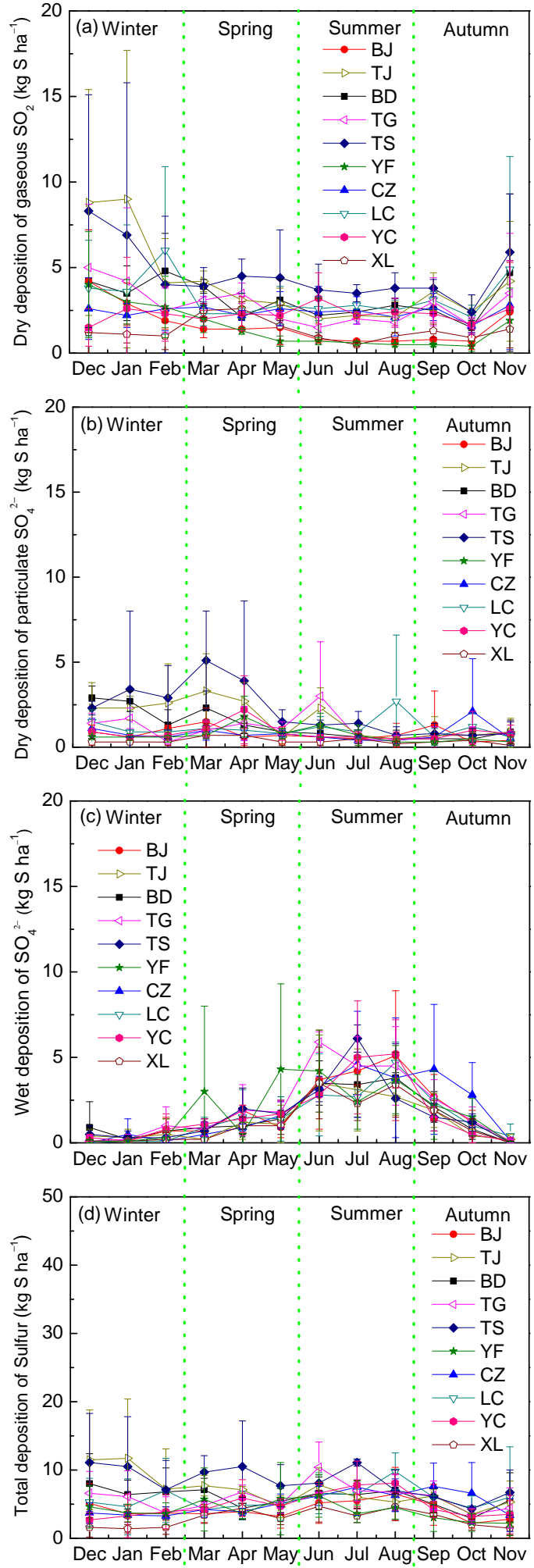

Fig. 3. Seasonal variations of the atmospheric deposition flux of sulfur at the ten selected sites in Northern China. The data shown are the monthly mean \pm standard deviations of 3-yr observations (from December 2007 to November 2010). The definition of the site codes is found in Sect. 2.1. than that at TJ. From the above analysis, it is difficult to conclude that the surface concentration is the major variable determining the spatial variations of $\mathrm{SO}_{4}^{2-}$. An intensive field observation of the chemical composition of the size-resolved particles alongside the dry deposition flux is underway. This study will clarify how and to what extent the concentrations can affect the dry deposition levels.

\subsection{Wet deposition of $\mathrm{SO}_{4}^{2-}$}

\subsubsection{Spatial variations of ${ }_{\mathrm{w}} \mathrm{SO}_{4}^{2-}$}

The mean annual ${ }_{\mathrm{w}} \mathrm{SO}_{4}^{2-}$ at the ten sites was relatively high and varied from 14.6 to $24.7 \mathrm{~kg} \mathrm{Sha}^{-1} \mathrm{yr}^{-1}$ with an average of $19.6 \mathrm{~kg} \mathrm{Sha}^{-1} \mathrm{yr}^{-1}$ during the $3-\mathrm{yr}$ study period (Table 1). This result is comparable to the values obtained for Jiangxi (17.2 $\mathrm{kg} \mathrm{Sha}^{-1} \mathrm{yr}^{-1}$ ) (Wang et al., 2003) and four other Chinese subtropical forest catchments (14.4-30.4 $\mathrm{kg} \mathrm{S} \mathrm{ha}^{-1} \mathrm{yr}^{-1}$ ) (Larssen et al., 2011) but is much higher than the modeled ${ }_{\mathrm{w}} \mathrm{SO}_{4}^{2-}$ for Hong Kong (9.6 $\mathrm{kg} \mathrm{Sha}^{-1} \mathrm{yr}^{-1}$ ) (Ayers and Yeung, 1996) and the values (3.8-11.2 $\mathrm{kg} \mathrm{S} \mathrm{ha}^{-1} \mathrm{yr}^{-1}$ ) reported by CASTNET, EMEP and EANET (Endo et al., 2010).

In the present study, the largest values were observed at TG $\left(24.7 \mathrm{~kg} \mathrm{Sha}^{-1} \mathrm{yr}^{-1}\right)$ followed by $\mathrm{CZ}$ $\left(22.9 \mathrm{~kg} \mathrm{Sha}^{-1} \mathrm{yr}^{-1}\right)$. The ${ }_{\mathrm{w}} \mathrm{SO}_{4}^{2-}$ was similar in BJ, TS and $\mathrm{YC}$, with high values of $21.5,20.8$ and $20.3 \mathrm{~kg} \mathrm{Sha}^{-1} \mathrm{yr}^{-1}$, respectively. At $\mathrm{YF}, \mathrm{BD}$ and $\mathrm{LC}$, the ${ }_{\mathrm{w}} \mathrm{SO}_{4}^{2-}$ was moderately large at $19.2,18.8$ and $17.9 \mathrm{~kg} \mathrm{~S} \mathrm{ha}^{-1} \mathrm{yr}^{-1}$, respectively. The relatively low flux occurred at $\mathrm{TJ}\left(15.5 \mathrm{~kg} \mathrm{Sha}^{-1} \mathrm{yr}^{-1}\right)$, and as expected, the $3-\mathrm{yr}$ mean values were the lowest at $\mathrm{XL}$ $\left(14.6 \mathrm{~kg} \mathrm{Sha}^{-1} \mathrm{yr}^{-1}\right)$. However, the differences were not significant $(p>0.05)$ among the sites or the different years, indicating the absence of a geographic pattern in the spatial distribution of ${ }_{\mathrm{w}} \mathrm{SO}_{4}^{2-}$ in Northern China.

\subsubsection{Factors affecting the spatial pattern of ${ }_{w} \mathrm{SO}_{4}^{2-}$}

With the aim of identifying potential factors that influence the spatial pattern of wet depositions, we performed a statistical analysis of the data from the 3-yr period following the previous studies (Sakata et al., 2006). It was assumed that if the scavenging ratios $(W)$ and the atmospheric concentrations $\left(C_{\mathrm{a}}\right)$ are constant in the study area, the wet deposition flux $(F)$ would increase in proportion to the amount of precipitation $(P)$ according to the relationship given by

$F=W C_{\mathrm{a}} P$

The results illustrated a moderately linear relationship between the annual ${ }_{\mathrm{w}} \mathrm{SO}_{4}^{2-}$ and the corresponding precipitation amounts $\left(r^{2}=0.23, p<0.05\right)$. However, only $23 \%$ of the variance of ${ }_{\mathrm{w}} \mathrm{SO}_{4}^{2-}$ was explained by the annual precipitation (Fig. 4a), implying marked differences in the scavenging ratio and the atmospheric concentrations of $\mathrm{SO}_{\mathrm{x}}$ across 

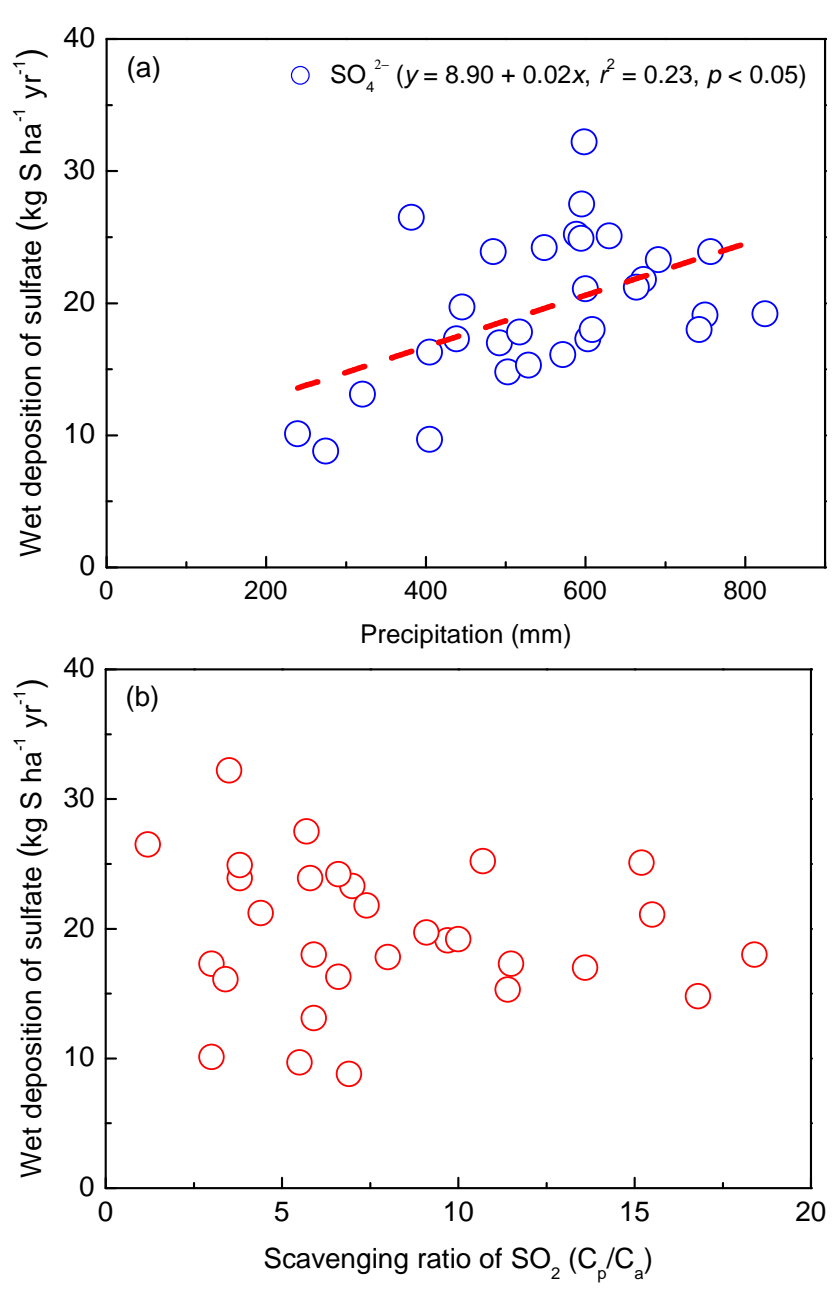

Fig. 4. Annual wet deposition flux of sulfur vs. precipitation amount (a) and scavenging ratios of $\mathrm{SO}_{2}$ (b) at the ten selected sites in Northern China.

Northern China, which is similar to that of $\mathrm{NH}_{4}^{+}$(Pan et al., 2012).

To further examine whether the scavenging ratios are the main factors influencing the annual ${ }_{\mathrm{w}} \mathrm{SO}_{4}^{2-}$, the scavenging ratios were calculated on a mass basis by the following relationship:

$W=C_{\mathrm{p}} / C_{\mathrm{a}}$.

The concept of the scavenging ratios is based on the simplified assumption that the concentrations of $\mathrm{SO}_{4}^{2-}$ in precipitation $\left(\mathrm{C}_{\mathrm{p}}\right)$ depend on the ambient concentrations of $\mathrm{SO}_{2}$ or $\mathrm{SO}_{4}^{2-}$. As the data set of $\mathrm{SO}_{4}^{2-}$ was not sufficient to perform such an analysis, we only performed a scatter plot of ${ }_{w} \mathrm{SO}_{4}^{2-}$ with the scavenging ratios of $\mathrm{SO}_{2}$ (Fig. 4b). There was no clear relationship between ${ }_{\mathrm{w}} \mathrm{SO}_{4}^{2-}$ and the scavenging ratio of $\mathrm{SO}_{2}$, implying that the scavenging ratio may not be the main cause for the regional differences of ${ }_{\mathrm{w}} \mathrm{SO}_{4}^{2-}$. In addition, there is also no evidence that the differences were caused by the surface concentrations of $\mathrm{SO}_{2}$ or $\mathrm{SO}_{4}^{2-}$, as demonstrated in Fig. 2a and b.

To avoid confusion, it is worth noting that the wet deposition amount includes contributions from both in-cloud scavenging (most of which might be from long-range transport) and below-cloud scavenging (part of which might also be from long-range transport) (Ichikawa and Fujita, 1995; Wiegand et al., 2011). Therefore, wet deposition at a given site is expected to be influenced by a broader area than only local emissions. In addition to the precipitation amount, differences in the column concentrations are likely to be the main causes of spatial variations of ${ }_{\mathrm{w}} \mathrm{SO}_{4}^{2-}$. This assumption is partially supported by the fact that the concentrations of $\mathrm{SO}_{2}$ increased with height in the atmospheric boundary layer and reached a maximum at $100 \mathrm{~m}$ or higher (Meng et al., 2008; Sun et al., 2009). Such a vertical distribution is reasonable because $\mathrm{SO}_{2}$ mostly originates from the higher $(>60 \mathrm{~m})$ stacks of the power plants and industrial buildings and not from near the ground. The vertical profile of $\mathrm{SO}_{2}$ was most likely the main reason for the discrepancy between the surface concentrations and wet depositions. From the above analysis, we arrived at the major conclusion that wet deposition has less dependence on local emissions because it depends primarily on column concentration and in-cloud scavenging.

\subsubsection{Seasonal variations of ${ }_{\mathrm{w}} \mathrm{SO}_{4}^{2-}$}

The mean monthly ${ }_{\mathrm{w}} \mathrm{SO}_{4}^{2-}$ monitored for the three years ranged from 0 to $6.1 \mathrm{~kg} \mathrm{Sha}^{-1}$ month $^{-1}$ (Fig. 3c). The seasonal variations of ${ }_{\mathrm{w}} \mathrm{SO}_{4}^{2-}$ showed similar trends at each site, with a maximum in summer and minimum in winter. The ${ }_{\mathrm{w}} \mathrm{SO}_{4}^{2-}$ was high in June, July, August and September, corresponding with the rainy season in Northern China. In contrast, the minimum ${ }_{\mathrm{w}} \mathrm{SO}_{4}^{2-}$ that was obtained in the winter months was attributable to a low level of precipitation. In general, a significant linear correlation between the monthly ${ }_{w} \mathrm{SO}_{4}^{2-}$ and precipitation was observed at each site $\left(0.52<r^{2}<0.93, p<0.001\right)$. Therefore, the precipitation amount is likely to be very important in explaining the seasonal trend of ${ }_{\mathrm{w}} \mathrm{SO}_{4}^{2-}$ detected at a given site.

\subsection{Atmospheric total S deposition}

\subsubsection{Spatio-temporal variations of ${ }_{t} \mathrm{SO}_{\mathrm{x}}$ in Northern China}

The mean annual ${ }_{\mathrm{t}} \mathrm{SO}_{\mathrm{x}}$ estimated in this study ranged from 35.0 to $100.7 \mathrm{~kg} \mathrm{Sha}^{-1} \mathrm{yr}^{-1}$ over the 3 -yr sampling period at the ten sites (Table 1). With the exception of BD, LC and TJ, the year-to-year variations in the annual average ${ }_{t} \mathrm{SO}_{\mathrm{x}}$ at the sites were not significant $(p>0.05)$. Nevertheless, a declining tendency was found for sites BD, BJ, LC and TS, whereas the interannual variations at the other sites were more ambiguous. The discrepancy of interannual ${ }_{t} \mathrm{SO}_{\mathrm{x}}$ trends among 
the sites is reasonable because the year-to-year variations of ${ }_{\mathrm{w}} \mathrm{SO}_{4}^{2-}$ and $\mathrm{SO}_{4}^{2-}$ did not show any marked trend. As presented in Fig. 3d, the monthly mean ${ }_{t} \mathrm{SO}_{\mathrm{x}}$ during the 3-yr period ranged from 1.4 to $11.7 \mathrm{~kg} \mathrm{~S} \mathrm{ha}^{-1} \mathrm{month}^{-1}$. However, the seasonal trends at most sites did not significantly differ, indicating that ${ }_{\mathrm{t}} \mathrm{SO}_{\mathrm{x}}$ was constant throughout the entire year as a result of opposite seasonal trends of wet vs. dry deposition of $\mathrm{S}$ at a given site.

The spatial variation of ${ }_{\mathrm{t}} \mathrm{SO}_{\mathrm{x}}$ was in agreement with that of gaseous and particulate dry deposition; the values at $\mathrm{LC}$, $\mathrm{BD}, \mathrm{TG}, \mathrm{CZ}$ and $\mathrm{YC}$ were higher than those at $\mathrm{BJ}, \mathrm{YF}$ and $\mathrm{XL}$ and lower than those at TS and TJ. The overall mean ${ }_{t} \mathrm{SO}_{\mathrm{x}}$ in Northern China was $64.8 \mathrm{~kg} \mathrm{Sha}^{-1} \mathrm{yr}^{-1}$ during the 3 -yr period, which was approximately 4 to 10 times that of the values of $6.2,6.2$ and $17.6 \mathrm{~kg} \mathrm{Sha}^{-1} \mathrm{yr}^{-1}$ reported by CASTNET, EMEP and EANET, respectively (Endo et al., 2010). As most sites in these overseas networks were located in less polluted areas, perhaps using the rural site XL as the critical baseline for heavy S deposition would be more reflective of the effects of human-induced emissions in the target area. Despite the above consideration, the ${ }_{t} \mathrm{SO}_{\mathrm{x}}$ at $\mathrm{XL}$ ( $35.0 \mathrm{~kg} \mathrm{Sha}^{-1} \mathrm{yr}^{-1}$ ) was approximately 2 to 5 times that observed by the above-listed monitoring networks, indicating a high level of $\mathrm{S}$ deposition in Northern China as a result of massive $\mathrm{SO}_{2}$ emissions.

In addition, the total $\mathrm{S}$ deposition at XL was likely to have been underestimated because fog water is an important atmospheric deposition process in mountainous forest areas but was not measured in this study. However, the rate of S deposition via fog, wet and dry deposition in high-elevation forests in the US (16.3 $\mathrm{kg} \mathrm{Sha}^{-1} \mathrm{yr}^{-1}$ ) (Miller et al., 1993) and Japan (16.7-27.7 $\mathrm{kg} \mathrm{Sha}^{-1} \mathrm{yr}^{-1}$ ) (Shimadera et al., 2012) was also significantly lower than that of the present study. Future estimates from CMAQ simulations indicate that northcentral and eastern China are expected to receive the highest $\mathrm{S}$ depositions resulting from a high density of energy consumption and emissions (Zhao et al., 2009). In addition to the present field-based data, the predicted spatial pattern of $\mathrm{S}$ deposition in China can be further confirmed by the fact that the total airborne $\mathrm{SO}_{\mathrm{x}}$ input into the farmland in Jiangxi, China, is estimated to be $103 \mathrm{~kg} \mathrm{Sha}^{-1} \mathrm{yr}^{-1}$ (Wang et al., 2003), which is greater than the results found for the agricultural sites of LC and YC (70.1 and $58.0 \mathrm{~kg} \mathrm{Sha}^{-1} \mathrm{yr}^{-1}$, respectively) in this study. Therefore, the sufficiently high $\mathrm{S}$ deposition in vast areas in China suggests the need for an integrated assessment of the effects of excess $\mathrm{S}$ deposition in different ecosystems.

To address the above concerns and help policy-makers mitigate $\mathrm{S}$ deposition, the sources of $\mathrm{SO}_{2}$ must be identified. An emissions inventory of $\mathrm{SO}_{2}$ may support the hypothesis of significant influences of human activity on the $\mathrm{S}$ deposition budget in the target area (Fig. 1b). On one hand, relatively low ${ }_{\mathrm{t}} \mathrm{SO}_{\mathrm{x}}$ was observed at $\mathrm{XL}$ and $\mathrm{YF}$ as a result of fewer anthropogenic emissions. On the other hand, relatively high ${ }_{\mathrm{t}} \mathrm{SO}_{\mathrm{x}}$ was found at TS, TJ, BD and $\mathrm{LC}$, which are surrounded by large $\mathrm{SO}_{2}$ emissions sources. Therefore, ${ }_{t} \mathrm{SO}_{\mathrm{x}}$ tends to increase in relation to human-induced $\mathrm{SO}_{2}$ emissions, and a spatial pattern is identifiable here. Although the discrepancy between the emissions and depositions observed at BJ and YC may be attributable to overestimations in the current gridded inventories of INTEX-B, low emissions and high deposition at $\mathrm{CZ}$ and TG most likely indicate underestimations of $\mathrm{SO}_{2}$ emissions in the areas surrounding these sites. In addition, differences in the spatial resolution also contribute to the inconsistencies between the emissions and depositions. To help policy-makers implement sourcecontrol decisions, additional research is needed to validate the emissions data presented here.

\subsubsection{Contribution of different pathways to ${ }_{t} \mathrm{SO}_{\mathrm{x}}$}

Among the three deposition pathways, $\mathrm{g}_{\mathrm{SO}}$ was the major contributor of $\mathrm{H}_{\mathrm{SO}}$ at most sites, and the contribution ranged from $39 \%$ (BJ) to $58 \%$ (TJ), with an average of $49 \%$. The deposition of $\mathrm{S}$ through $\mathrm{gSO}_{2}$ was greater than $50 \%$ at $\mathrm{TJ}$, $\mathrm{BD}$, TS and $\mathrm{LC}$, which is due in part to the proximity of the sites to high-emissions areas. $\mathrm{SO}_{4}^{2-}$ contributed $19-43 \%$ of the ${ }_{\mathrm{t}} \mathrm{SO}_{\mathrm{x}}$, with a ten-site, 3 -yr mean of $32 \%$, which was $17 \%$ lower than that of $\mathrm{gSO}_{2}$. Notably, the contribution of ${ }_{\mathrm{w}} \mathrm{SO}_{4}^{2-}$ to ${ }_{\mathrm{t}} \mathrm{SO}_{\mathrm{x}}$ exceeded that of $\mathrm{gSO}_{2}$ at the $\mathrm{BJ}$ and $\mathrm{YF}$ sites, implying that precipitation was the largest contributor to the total $\mathrm{S}$ deposition. Compared to $\mathrm{gSO}_{2}$ and ${ }_{\mathrm{w}} \mathrm{SO}_{4}^{2-}$, the proportion of $\mathrm{SO}_{4}^{2-}$ to ${ }_{\mathrm{H}} \mathrm{SO}_{\mathrm{x}}$ was relatively small, falling in the range of $13-25 \%$, with an average of $19 \%$. It is worth noting that the contribution of ${ }_{\mathrm{p}} \mathrm{SO}_{4}^{2-}$ to ${ }_{\mathrm{t}} \mathrm{SO}_{\mathrm{x}}$ exceeded that of ${ }_{\mathrm{w}} \mathrm{SO}_{4}^{2-}$ at the $\mathrm{TJ}$ and TS sites, which reflects the intense perturbation of the atmospheric particulate $\mathrm{SO}_{4}^{2-}$ by anthropogenic activities.

The measurements obtained in this study allowed us to systematically evaluate the $\mathrm{S}$ deposition via different pathways in Northern China, whereas previous studies only focused on either the wet (Yang et al., 2012) or the dry deposition (Meng et al., 2010; Lin et al., 2012). Overall, the precipitation, particulate and gas dry deposition accounted for $32 \%, 19 \%$ and $49 \%$, respectively, of the total S deposition in Northern China. The $\mathrm{S}$ deposition pattern was similar to that of $\mathrm{N}$, which showed the largest contribution of gas (50\%), followed by precipitation (40\%) and particles (10\%) (Pan et al., 2012). However, the contribution of precipitation to the total $\mathrm{S}$ deposition was $8 \%$ lower than that of $\mathrm{N}$, whereas the contribution of the particulate dry deposition to the total S deposition was twice that of N. These differences most likely indicate that the particulate dry deposition played a more important role in the $\mathrm{S}$ deposition than that of $\mathrm{N}$. One study conducted in Southern China also demonstrated that the largest input of atmospheric $\mathrm{S}$ into the farmland ecosystem was gas (77\%), followed by rainwater $(17 \%)$ and particles $(6 \%)$ (Wang et al., 2003). The relatively high $\mathrm{SO}_{2}$ dry deposition and its role in the total $\mathrm{S}$ deposition most likely reflect heavy $\mathrm{SO}_{2}$ pollution in China emitted from anthropogenic sources. 


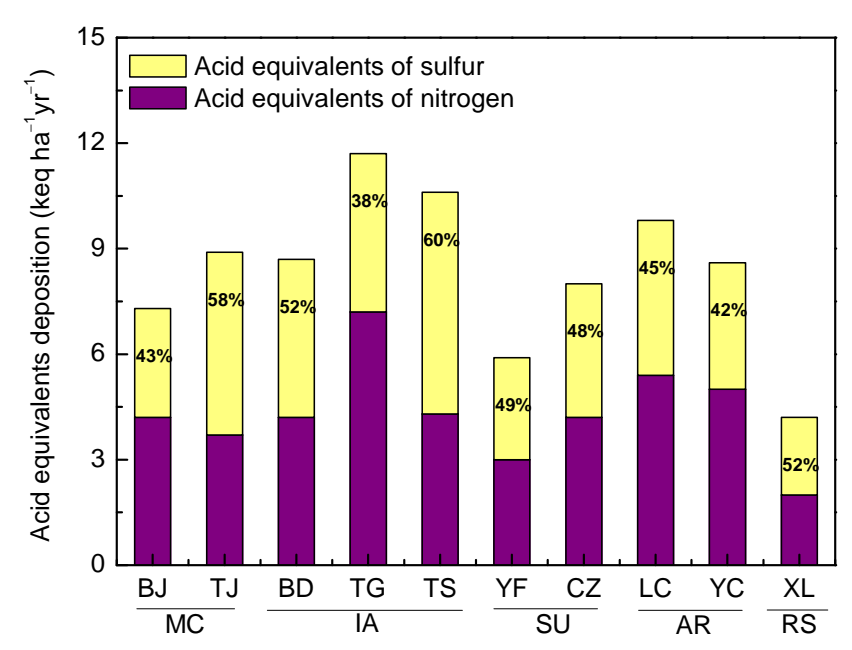

Fig. 5. Total "acid equivalents" deposition of sulfur and nitrogen at the ten selected sites in Northern China. The data shown are means of 3-yr observations. MC, IA, SU, AR and RS denote urban, industrial, suburban, agricultural and rural sites, respectively. Percentage in each bar represents the proportion of sulfur contribution to acid equivalent deposition at the corresponding site. The definition of the site codes is found in Sect. 2.1.

\subsubsection{Acid deposition in Northern China and its implications}

Wet deposition of $\mathrm{SO}_{4}^{2-}$ has been widely documented due to concerns about the impacts of this deposited compound on the acidity of the environment. In addition to precipitation, dry-deposited $\mathrm{SO}_{4}^{2-}$ and $\mathrm{SO}_{2}$ also contribute to the acidification of ecosystems. Therefore, there is a necessity for the quantification of total $\mathrm{S}$ deposition to develop the control strategies for atmospheric pollution. Specifically, the total S deposition in this study ranged from 2.2 to $6.3 \mathrm{keq} \mathrm{ha}^{-1} \mathrm{yr}^{-1}$, with a ten-site mean of $4.1 \mathrm{keq} \mathrm{ha}^{-1} \mathrm{yr}^{-1}$ (Fig. 5), which is much higher than the critical loads $\left(<2.0 \mathrm{keq} \mathrm{ha}^{-1} \mathrm{yr}^{-1}\right)$ for acidification in most areas of Northern China (Zhao et al., 2009). Because the critical loads are defined as indicators of ecosystem sensitivity, the total $\mathrm{S}$ deposition exceeding the critical loads indicates that harmful ecological effects will occur or may have already occurred (Larssen et al., 2011). In addition, Northern China is currently receiving $\mathrm{N}$ deposition at rates higher than the critical loads (Pan et al., 2012), and modeling results predict that the region will likely receive increased $\mathrm{N}$ deposition in the future (Zhao et al., 2009). Therefore, long-term impacts of $\mathrm{N}$ and its combined effects with $\mathrm{S}$ in driving the acidification of terrestrial and aquatic ecosystems are expected.

With the aim of determining the contribution of acidifying species into the environment, the total deposition of the "acid equivalents" of $\mathrm{S}$ and $\mathrm{N}$ was estimated by summing the wet and the particulate dry deposition flux of $\mathrm{SO}_{4}^{2-}, \mathrm{NO}_{3}^{-}, \mathrm{NO}_{2}^{-}$ and $\mathrm{NH}_{4}^{+}$and the estimated gas dry deposition flux of $\mathrm{SO}_{2}$, $\mathrm{NO}_{2}, \mathrm{NO}$ and $\mathrm{NH}_{3}$. Taking $\mathrm{N}$ deposition data from our com- panion paper into account (Pan et al., 2012), the total acid deposition ranged from 4.2 to $11.6 \mathrm{keq} \mathrm{ha}^{-1} \mathrm{yr}^{-1}$, with a tensite mean of $8.4 \mathrm{keq} \mathrm{ha}^{-1} \mathrm{yr}^{-1}$ (Fig. 5), which fall within the range of 1.9-13 keq ha-1 $\mathrm{yr}^{-1}$ in the forested catchments in Southern China (Larssen et al., 2011). However, the acid deposition in the study is approximately 10 times the results in Malaysia (0.3-0.5 keq ha ${ }^{-1} \mathrm{yr}^{-1}$ ) (Ayers et al., 2000) and is also much higher than the earlier estimates from highelevation forests in the US $\left(2.2 \mathrm{keq} \mathrm{ha}^{-1} \mathrm{yr}^{-1}\right.$ ) (Miller et al., 1993) and the values $\left(0.8-1.9 \mathrm{keq} \mathrm{ha}^{-1} \mathrm{yr}^{-1}\right)$ reported by CASTNET, EMEP and EANET (Endo et al., 2010). The level of acid deposition in Northern China is sufficiently high to suggest the need for an integrated assessment of the acidic deposition and its potential environmental consequences for the region (Hao et al., 2001; Larssen et al., 2011; Yang et al., 2012b; Zhao et al., 2009).

The atmospheric deposition of $\mathrm{S}$ has been of interest for many years. However, the importance of $\mathrm{N}$ on acidification risks is clearly demonstrated in our study if the acidification effect of $\mathrm{N}$ is combined with that of $\mathrm{S}$. As illustrated in Fig. 5, the contribution of $\mathrm{N}$ to acid deposition was higher than that of $\mathrm{S}$ at most sites, with the exception of TS, TJ, BD and XL. The relatively high contribution of $\mathrm{S}$ to the total acid deposition at these four sites highlights the fact that further $\mathrm{SO}_{2}$ abatement in the industrial regions is required, considering the large $\mathrm{S}$ deposition in the rural areas of Northern China. It should be noted that the contribution of $\mathrm{S}$ to the total acid deposition was almost in the same range as that of $\mathrm{N}$ at most of the sites (Fig. 5), with the exception of BJ, TG, YC and LC, where $\mathrm{NH}_{3}$ deposition is high (Pan et al., 2012). Therefore, to mitigate acid deposition and alleviate its potential impacts on ecosystems, a multi-pollutant perspective and joint control strategies to abate $\mathrm{SO}_{2}$ and $\mathrm{NH}_{3}$ simultaneously in the target area are recommended (Zhao et al., 2009).

\section{Conclusions}

An observation network has been organized to investigate the spatial distribution and temporal variations of atmospheric deposition via precipitation (wet deposition) and as particles and gases (dry deposition) in Northern China since late 2007. This paper presents an analysis of the measured and estimated total sulfur deposition during a 3 -yr period at ten selected sites, representing by far the most detailed data set prepared to track the acid deposition in Northern China. Such a data set for this region is needed for ecosystem studies and for developing emissions control policies. The major findings are as follows.

1. Both $\mathrm{gSO}_{2}$ and $\mathrm{SO}_{4}^{2-}$ showed clear spatial variations, with higher values observed at industrial and urban sites than at agricultural and rural sites. The anthropogenic imprints on the regional pattern of $\mathrm{gSO}_{2}$ are evident because this measure is mostly determined by the surface concentration, which closely associated with the 
local emissions. Nevertheless, the regional mismatch between the concentrations of $\mathrm{SO}_{4}^{2-}$ and $\mathrm{pSO}_{4}^{2-}$ indicates that the surface concentration is unlikely to be the major variable determining the spatial distributions of $\mathrm{SO}_{4}^{2-}$. In addition, seasonal variations of $\mathrm{SO}_{2}$ and $\mathrm{pSO}_{4}^{2-}$ coincide with the ambient concentrations of $\mathrm{SO}_{2}$ and $\mathrm{SO}_{4}^{2-}$ in coarse particles, both of which exhibited relatively large values during the cold season due to the local emissions from home heating.

2. The seasonal variations were distinct in ${ }_{\mathrm{w}} \mathrm{SO}_{4}^{2-}$, with higher values observed in the summer than in other seasons, corresponding to the seasonal trend of precipitation in Northern China. However, the spatial differences in the ${ }_{\mathrm{w}} \mathrm{SO}_{4}^{2-}$ were not significant among the ten sites or among the different years. The regional pattern of ${ }_{\mathrm{w}} \mathrm{SO}_{4}^{2-}$ was more influenced by the precipitation amount but is less dependent on the local emissions because it includes the column concentrations of $\mathrm{S}$ compounds in the air and the in-cloud scavenging. This fact was further supported by the regional discrepancy between ${ }_{\mathrm{w}} \mathrm{SO}_{4}^{2-}$ and surface concentrations of $\mathrm{SO}_{2}$ and $\mathrm{SO}_{4}^{2-}$.

3. As a result of opposite seasonal trends of wet vs. dry deposition, the seasonal changes of ${ }_{\mathrm{t}} \mathrm{SO}_{\mathrm{x}}$ were not obvious during the entire year. In contrast, the spatial variations of ${ }_{\mathrm{t}} \mathrm{SO}_{\mathrm{x}}$ were evident and were observed to be similar to that of dry deposition, which compared well with the regional pattern of the emissions inventory. $\mathrm{gSO}_{2}$ contributed the most $(49 \%)$ to the ${ }_{\mathrm{t}} \mathrm{SO}_{\mathrm{x}}$ $\left(64.8 \mathrm{~kg} \mathrm{Sha}^{-1} \mathrm{yr}^{-1}\right)$, whereas ${ }_{\mathrm{w}} \mathrm{SO}_{4}^{2-}$ and ${ }_{\mathrm{p}} \mathrm{SO}_{4}^{2-}$ accounted for $32 \%$ and $19 \%$, respectively, of the total deposition. This unique data set provides field-based evidence that the ${ }_{t} \mathrm{SO}_{\mathrm{x}}$ in Northern China is significantly higher than in other regions of the world. The results also indicate that dry deposition is an important deposition process in the target area and that wet deposition cannot be used in isolation to determine ${ }_{t} \mathrm{SO}_{\mathrm{x}}$.

Although the concentrations of $\mathrm{SO}_{2}$ decreased every year during 2008-2010, which is in line with the declining trend of the $\mathrm{SO}_{2}$ emissions since 2006, the interannual trends of $\mathrm{S}$ deposition were more ambiguous, highlighting the fact that future studies should focus on the long-term monitoring of $\mathrm{S}$ deposition in the context of evaluating the efficiency of the control measures and impacts on the ecosystems. If the acidification effect of $\mathrm{S}$ is combined with that of $\mathrm{N}$, the estimated acid deposition exceeds the critical loads for the natural ecosystems, prompting concerns regarding ecological impacts. The contribution of $\mathrm{S}$ to the total acid deposition is at the same level as that of $\mathrm{N}$ at most of the sites. However, the acidification risks of $\mathrm{S}$ were more pronounced in the industrial areas. To mitigate acid deposition in the target area, pri- ority should be given to strategies that ameliorate the effects of $\mathrm{SO}_{2}$ and $\mathrm{NH}_{3}$ simultaneously.

Acknowledgements. This work was supported by the Knowledge Innovation Project of the Chinese Academy of Sciences (No.: KZCX1-YW-06-01), the National Basic Research Program of China (No.: 2012CB417100 and 2007CB407303), the CAS Strategic Priority Research Program (No.: XDA05100100), the Science and Technology Project of Beijing (No.: D09040903670902) and the National Natural Science Foundation of China (No.: 41230642 and 41021004). Special thanks go to H. Tang, W. Liu, W. Wang, G. Fu, Y. Chang, X. Feng, Y. Cheng, C. Zhang, Z. Liu and other staff who collected the samples at the ten monitoring sites. The authors would like to thank two anonymous reviewers for very helpful comments and suggestions.

Edited by: K. Schaefer

\section{References}

Aherne, J. and Farrell, E. P.: Deposition of sulphur, nitrogen and acidity in precipitation over Ireland: chemistry, spatial distribution and long-term trends, Atmos. Environ., 36, 1379-1389, doi:10.1016/S1352-2310(01)00507-6, 2002.

Ayers, G. P. and Yeung, K. K.: Acid deposition in Hong Kong, Atmos. Environ., 30, 1581-1587, doi:10.1016/13522310(95)00454-8, 1996.

Ayers, G. P., Peng, L. C., Fook, L. S., Kong, C. W., Gillett, R. W., and Manins, P. C.: Atmospheric concentrations and deposition of oxidised sulfur and nitrogen species at Petaling Jaya, Malaysia, 1993-1998, Tellus. B, 52, 60-73, doi:10.1034/j.16000889.2000.00043.x, 2000.

Balestrini, R., Galli, L., and Tartari, G.: Wet and dry atmospheric deposition at prealpine and alpine sites in northern Italy, Atmos. Environ., 34, 1455-1470, doi:10.1016/s1352-2310(99)00404-5, 2000.

Brook, J. R., Zhang, L., Li, Y., and Johnson, D.: Description and evaluation of a model of deposition velocities for routine estimates of dry deposition over North America. Part II: review of past measurements and model results, Atmos. Environ., 33, 5053-5070, doi:10.1016/s1352-2310(99)00251-4, 1999.

Byun, D. W. and Ching, J. K. S.: Science algorithms of the EPA Models-3 community multiscale air quality (CMAQ) modeling system; Report EPA/600/R-99/030, US Environmental Protection Agency: Research Triangle Park, NC, USA, 1999.

Costabile, F., Bertoni, G., Desantis, F., Wang, F., Weimin, H., Fenglei, L., and Allegrini, I.: A preliminary assessment of major air pollutants in the city of Suzhou, China, Atmos. Environ., 40, 6380-6395, doi:10.1016/j.atmosenv.2006.05.056, 2006.

Driscoll, C. T., Lawrence, G. B., Bulger, A. J., Butler, T. J., Cronan, C. S., Eagar, C., Lambert, K. F., Likens, G. E., Stoddard, J. L., and Weathers, K. C.: Acidic deposition in the northeastern United States: sources and inputs, ecosystem effects, and management strategies, Biosciences, 51, 180-198, doi:10.1641/0006-3568(2001)051[0180:ADITNU]2.0.CO;2, 2001.

Endo, T., Yagoh, H., Sato, K., Matsuda, K., Hayashi, K., Noguchi, I., and Sawada, K.: Regional characteristics of dry deposi- 
tion of sulfur and nitrogen compounds at EANET sites in Japan from 2003 to 2008, Atmos. Environ., 45, 1259-1267 doi:10.1016/j.atmosenv.2010.12.003, 2010.

Fang, Y. T., Koba, K., Wang, X. M., Wen, D. Z., Li, J., Takebayashi, Y., Liu, X. Y., and Yoh, M.: Anthropogenic imprints on nitrogen and oxygen isotopic composition of precipitation nitrate in a nitrogen-polluted city in Southern China, Atmos. Chem. Phys., 11, 1313-1325, doi:10.5194/acp-11-1313-2011, 2011.

Feliciano, M. S., Pio, C. A., and Vermeulen, A. T.: Evaluation of $\mathrm{SO}_{2}$ dry deposition over short vegetation in Portugal, Atmos. Environ., 35, 3633-3643, doi:10.1016/s1352-2310(00)00539-2, 2001.

Flechard, C. R., Nemitz, E., Smith, R. I., Fowler, D., Vermeulen, A. T., Bleeker, A., Erisman, J. W., Simpson, D., Zhang, L., and Tang, Y. S.: Dry deposition of reactive nitrogen to European ecosystems: a comparison of inferential models across the NitroEurope network, Atmos. Chem. Phys., 11, 2703-2728, doi:10.5194/acp-11-2703-2011, 2011.

Galloway, J. N., Likens, G. E., and Hawley, M. E.: Acid precipitation: natural versus anthropogenic components, Science, 226, 829-831, doi:10.1126/science.226.4676.829, 1984.

Galloway, J. N., Zhao, D. W., Xiong, J. L., and Likens, G. E.: Acid rain: China, United States, and a remote area, Science, 236, 1559-1562, doi:10.1126/science.236.4808.1559, 1987.

Hao, J., Duan, L., Zhou, X., and Fu, L.: Application of a LRT model to acid rain control in China, Environ. Sci. Technol., 35, 34073415, doi:10.1021/es001888u, 2001.

Huang, K., Zhuang, G., Xu, C., Wang, Y., and Tang, A.: The chemistry of the severe acidic precipitation in Shanghai, China, Atmos. Res., 89, 149-160, doi:10.1016/j.atmosres.2008.01.006, 2008.

Ichikawa, Y. and Fujita, S.: An analysis of wet deposition of sulfate using a trajectory model for East Asia, Water Air. Soil Poll., 85, 1927-1932, doi:10.1007/bf01186116, 1995.

Kuribayashi, M., Ohara, T., Morino, Y., Uno, I., Kurokawa, J., and Hara, H.: Long-term trends of sulfur deposition in East Asia during 1981-2005, Atmos. Environ., 59, 461-475, doi:10.1016/j.atmosenv.2012.04.060, 2012.

Larssen, T., and Carmichael, G. R.: Acid rain and acidification in China: the importance of base cation deposition, Environ. Pollut., 110, 89-102, doi:10.1016/s0269-7491(99)00279-1, 2000.

Larssen, T., Lydersen, E., Tang, D., He, Y., Gao, J., Liu, H., Duan, L., Seip, H. M., Vogt, R. D., and Mulder, J.: Acid rain in China, Environ. Sci. Technol., 40, 418-425, doi:10.1021/es0626133, 2006.

Larssen, T., Duan, L., and Mulder, J.: Deposition and leaching of sulfur, nitrogen and calcium in four forested catchments in China: Implications for acidification, Environ. Sci. Technol., 45, 1192-1198, doi:10.1021/es103426p, 2011.

Lestari, P., Oskouie, A. K., and Noll, K. E.: Size distribution and dry deposition of particulate mass, sulfate and nitrate in an urban area, Atmos. Environ., 37, 2507-2516, doi:10.1016/s13522310(03)00151-1, 2003.

Lin, W., Xu, X., Ma, Z., Zhao, H., Liu, X., and Wang, Y.: Characteristics and recent trends of sulfur dioxide at urban, rural, and background sites in North China: Effectiveness of control measures, J. Environ. Sci., 24, 34-49, doi:10.1016/s1001-0742(11)607274, 2012.
Liu, X. J., Duan, L., Mo, J. M., Du, E., Shen, J. L., Lu, X. K., Zhang, Y., Zhou, X. B., He, C. E., and Zhang, F. S.: Nitrogen deposition and its ecological impact in China: An overview, Environ. Pollut., 155, 2251-2264, doi:10.1016/j.envpol.2010.08.002, 2010.

Lu, Z., Streets, D. G., Zhang, Q., Wang, S., Carmichael, G. R., Cheng, Y. F., Wei, C., Chin, M., Diehl, T., and Tan, Q.: Sulfur dioxide emissions in China and sulfur trends in East Asia since 2000, Atmos. Chem. Phys., 10, 6311-6331, doi:10.5194/acp-106311-2010, 2010.

Meng, Z. Y., Ding, G. A., Xu, X. B., Xu, X. D., Yu, H. Q., and Wang, S. F.: Vertical distributions of $\mathrm{SO}_{2}$ and $\mathrm{NO}_{2}$ in the lower atmosphere in Beijing urban areas, China, Sci. Total. Environ., 390, 456-465, doi:10.1016/j.scitotenv.2007.10.012, 2008.

Meng, Z. Y., Xu, X. B., Wang, T., Zhang, X. Y., Yu, X. L., Wang, S. F., Lin, W. L., Chen, Y. Z., Jiang, Y. A., and An, X. Q.: Ambient sulfur dioxide, nitrogen dioxide, and ammonia at ten background and rural sites in China during 2007-2008, Atmos. Environ., 44, 2625-2631, doi:10.1016/j.atmosenv.2010.04.008, 2010.

Miller, E. K., Panek, J. A., Friedland, A. J., Kadlecek, J., and Mohnen, V. A.: Atmospheric deposition to a high-elevation forest at Whiteface Mountain, New York, USA, Tellus. B, 45, 209-227, doi:10.1034/j.1600-0889.1993.t01-2-00001.x, 1993.

Pan, Y. P., Wang, Y. S., Xin, J. Y., Tang, G. Q., Song, T., Wang, Y. H., Li, X. R., and Wu, F. K.: Study on dissolved organic carbon in precipitation in Northern China, Atmos. Environ., 44, 23502357, doi:10.1016/j.atmosenv.2010.03.033, 2010a.

Pan, Y. P., Wang, Y. S., Yang, Y. J., Wu, D., Xin, J. Y., and Fan, W. Y.: Determination of trace metals in atmospheric dry deposition with a heavy matrix of PUF by inductively coupled plasma mass spectroscopy after microwave digestion (in Chinese), Environ. Sci., 31, 553-559, 2010b.

Pan, Y. P., Wang, Y. S., Tang, G. Q., and Wu, D.: Wet and dry deposition of atmospheric nitrogen at ten sites in Northern China, Atmos. Chem. Phys., 12, 6515-6535, doi:10.5194/acp-12-65152012, 2012.

Park, S. U. and Lee, E. H.: Long-range transport contribution to dry deposition of acid pollutants in South Korea, Atmos. Environ., 37, 3967-3980, doi:10.1016/S1352-2310(03)00470-9, 2003.

Reuss, J. O., Cosby, B. J., and Wright, R. F.: Chemical processes governing soil and water acidification, Nature, 329, 2732, doi:10.1038/329027a0, 1987.

Rodhe, H., Dentener, F., and Schulz, M.: The global distribution of acidifying wet deposition, Environ. Sci. Technol., 36, 43824388, doi:10.1021/es020057g, 2002.

Sakata, M., Marumoto, K., Narukawa, M., and Asakura, K.: Regional variations in wet and dry deposition fluxes of trace elements in Japan, Atmos. Environ., 40, 521-531, doi:10.1016/j.atmosenv.2005.09.066, 2006.

Saxena, A., Kulshrestha, U. C., Kumar, N., Kumari, K. M., Prakash, S., and Srivastava, S. S.: Dry deposition of sulphate and nitrate to polypropylene surfaces in a semi-arid area of India, Atmos. Environ., 31, 2361-2366, doi:10.1016/s1352-2310(97)00052-6, 1997.

Schwede, D., Zhang, L., Vet, R., and Lear, G.: An intercomparison of the deposition models used in the CASTNET and CAPMoN networks, Atmos. Environ., 45, 1337-1346 doi:10.1016/j.atmosenv.2010.11.050, 2011.

Shen, J. L., Tang, A. H., Liu, X. J., Fangmeier, A., Goulding, K. T. W., and Zhang, F. S.: High concentrations and 
dry deposition of reactive nitrogen species at two sites in the North China Plain, Environ. Pollut., 157, 3106-3113, doi:10.1016/j.envpol.2009.05.016, 2009.

Shimadera, H., Kondo, A., Shrestha, K. L., Kaga, A., and Inoue, Y.: Annual sulfur deposition through fog, wet and dry deposition in the Kinki Region of Japan, Atmos. Environ., 45, 6299-6308, doi:10.1016/j.atmosenv.2011.08.055, 2012.

Sickles, J. E., Shadwick, D. S., Kilaru, J. V., and Grimm, J. W.: Errors in representing regional acid deposition with spatially sparse monitoring: Case studies of the eastern US using model predictions, Atmos. Environ., 43, 2855-2861, doi:10.1016/j.atmosenv.2009.03.018, 2009.

Sun, M., Wang, Y., Wang, T., Fan, S., Wang, W., Li, P., Guo, J., and $\mathrm{Li}$, Y.: Cloud and the corresponding precipitation chemistry in south China: Water-soluble components and pollution transport, J. Geophys. Res., 115, D22303, doi:10.1029/2010JD014315, 2010.

Sun, Y.: Chemical composition and mass closure of particulate matter in Beijing, Tianjin and Hebei megacities, Northern China, Ms. thesis, Capital Normal University, Beijing, 69 pp., 2011.

Sun, Y., Wang, Y., and Zhang, C.: Measurement of the vertical profile of atmospheric $\mathrm{SO}_{2}$ during the heating period in Beijing on days of high air pollution, Atmos. Environ., 43, 468-472, doi:10.1016/j.atmosenv.2008.09.057, 2009.

Tang, J., Xu, X. B., Ba, J., and Wang, S. F.: Trends of the precipitation acidity over China during 1992-2006, Chinese. Sci. Bull., 55, 1800-1807, doi:10.1007/s11434-009-3618-1, 2010.

Tsai, J. L., Chen, C. L., Tsuang, B. J., Kuo, P. H., Tseng, K. H., Hsu, T. F., Sheu, B. H., Liu, C. P., and Hsueh, M. T.: Observation of $\mathrm{SO}_{2}$ dry deposition velocity at a high elevation flux tower over an evergreen broadleaf forest in Central Taiwan, Atmos. Environ., 44, 1011-1019, doi:10.1016/j.atmosenv.2009.12.022, 2010.

Tsai, Y. I., Hsieh, L. Y., Kuo, S. C., Chen, C. L., and Wu, P. L.: Seasonal and rainfall-type variations in inorganic ions and dicarboxylic acids and acidity of wet deposition samples collected from subtropical East Asia, Atmos. Environ., 45, 3535-3547, doi:10.1016/j.atmosenv.2011.04.001, 2011.

Wai, K. M., Tanner, P. A., and Tam, C. W. F.: 2-year study of chemical composition of bulk deposition in a south China coastal city: Comparison with east Asian cities, Environ. Sci. Technol., 39, 6542-6547, doi:10.1021/es048897d, 2005.

Wang, T. J., Zhang, Y., Zhang, M., Hu, Z. Y., Xu, C. K., and Zhao, Y. W.: Atmoshperic sulfur deposition and the sulfur nutrition of crops at an agricututral site in Jiangxi province of China, Tellus. B, 55, 893-900, doi:10.1046/j.1435-6935.2003.00076.x, 2003.
Wang, Y., Yu, W., Pan, Y., and Wu, D.: Acid neutralization of precipitation in Northern China, J. Air. Waste. Manage., 62, 204211, doi:10.1080/10473289.2011.640761, 2012.

Wesely, M. L. and Hicks, B. B.: A review of the current status of knowledge on dry deposition, Atmos. Environ., 34, 2261-2282, doi:10.1016/s1352-2310(99)00467-7, 2000.

Wiegand, F., Pereira, F. N., and Teixeira, E. C.: Study on wet scavenging of atmospheric pollutants in south Brazil, Atmos. Environ., 45, 4770-4776, doi:10.1016/j.atmosenv.2010.02.020, 2011.

Wyers, G. P. and Duyzer, J. H.: Micrometeorological measurement of the dry deposition flux of sulphate and nitrate aerosols to coniferous forest, Atmos. Environ., 31, 333-343, doi:10.1016/S1352-2310(96)00188-4, 1997.

Yang, F., Tan, J., Shi, Z. B., Cai, Y., He, K., Ma, Y., Duan, F., Okuda, T., Tanaka, S., and Chen, G.: Five-year record of atmospheric precipitation chemistry in urban Beijing, China, Atmos. Chem. Phys., 12, 2025-2035, doi:10.5194/acp-12-2025-2012, 2012 a.

Yang, Y., Ji, C., Ma, W., Wang, S., Wang, S., Han, W., Mohammat, A., Robinson, D., and Smith, P.: Significant soil acidification across Northern China's grasslands during 1980s-2000s, Global. Change. Biol., 18, 2292-2300, doi:10.1111/j.13652486.2012.02694.x, 2012b.

Zhang, Q., Streets, D. G., Carmichael, G. R., He, K. B., Huo, H., Kannari, A., Klimont, Z., Park, I. S., Reddy, S., and Fu, J. S.: Asian emissions in 2006 for the NASA INTEX-B mission, Atmos. Chem. Phys., 9, 5131-5153, doi:10.5194/acp-9-5131-2009, 2009.

Zhang, X., Van Geffen, J., Liao, H., Zhang, P., and Lou, S.: Spatiotemporal variations of tropospheric SO2 over China by SCIAMACHY observations during 2004-2009, Atmos. Environ., 60, 238-246, doi:10.1016/j.atmosenv.2012.06.009, 2012.

Zhao, D., Xiong, J., Xu, Y., and Chan, W. H.: Acid rain in southwestern China, Atmos. Environ., 22, 349-358, doi:10.1016/00046981(88)90040-6, 1988.

Zhao, Y., Duan, L., Xing, J., Larssen, T., Nielsen, C. P., and Hao, J.: Soil acidification in China: Is controlling $\mathrm{SO}_{2}$ emissions enough?, Environ. Sci. Technol., 43, 8021-8026, doi:10.1021/es901430n, 2009. 